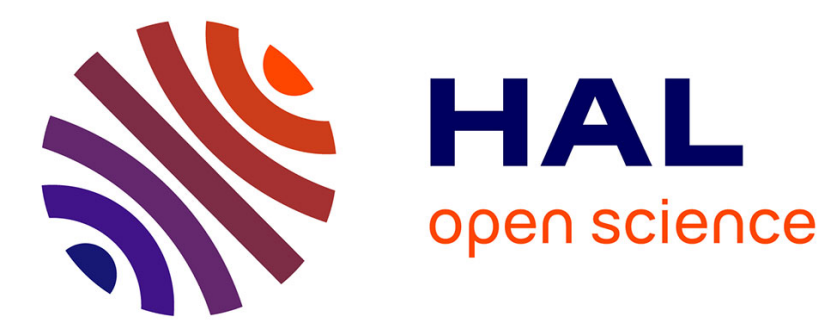

\title{
West African lateritic pediments: Landform-regolith evolution processes and mineral exploration pitfalls
}

Dominique Chardon, Jean-Louis Grimaud, Anicet Beauvais, Ousmane Bamba

\section{To cite this version:}

Dominique Chardon, Jean-Louis Grimaud, Anicet Beauvais, Ousmane Bamba. West African lateritic pediments: Landform-regolith evolution processes and mineral exploration pitfalls. Earth-Science Reviews, 2018, 179, pp.124-146. 10.1016/j.earscirev.2018.02.009 . hal-01744579

\section{HAL Id: hal-01744579 \\ https://hal-amu.archives-ouvertes.fr/hal-01744579}

Submitted on 27 Mar 2018

HAL is a multi-disciplinary open access archive for the deposit and dissemination of scientific research documents, whether they are published or not. The documents may come from teaching and research institutions in France or abroad, or from public or private research centers.
L'archive ouverte pluridisciplinaire HAL, est destinée au dépôt et à la diffusion de documents scientifiques de niveau recherche, publiés ou non, émanant des établissements d'enseignement et de recherche français ou étrangers, des laboratoires publics ou privés. 
1 West African lateritic pediments: Landform-regolith

2 evolution processes and mineral exploration pitfalls

3

4

5

6

7

8

9

10

11

12

13

14

15

16

17

18

19

20

21

22

$23{ }^{*}$ Corresponding author

24 E-mail address: dominique.chardon@ird.fr a IRD, 01 BP 182 Ouagadougou 01, Burkina Faso

b Département des Sciences de la Terre, Université Ouaga I Professeur Joseph Ki-Zerbo, BP 7021, Ouagadougou, Burkina Faso

‘GET, Université de Toulouse, CNRS, IRD, UPS, France.

d MINES ParisTech, PSL Research University, Centre de Géosciences,

35 rue St Honoré, 77305 Fontainebleau Cedex, France

e Aix-Marseille Univ, CNRS, IRD, Coll France, CEREGE BP 80,

13545 Aix-en-Provence, Cedex 4, France

Submitted to Earth-Science Reviews, 14 September 2017

Revised 28 January 2018

Accepted 09 February 2018

doi:10.1016/j.earscirev.2018.02.009 
27 - Review of the geomorphology, regolith and age of the West African pediment systems

28 - Duricrusted and loose transported sediments are dominant on pediments

29 - Specific geomorphological exploration guides are required for lateritic pediment terrains

30 - Pediments typify slow ( $<10 \mathrm{~m} / \mathrm{Ma}$ ) denudation regimes and their stepping patterns are not

31 gauges of regional uplift

32

33 Abstract

34 This paper is a contribution to the understanding of surface dynamics of tropical shields over 35 geological timescales. Emphasis is put on the fundamental and applied implications of 36 regolith production and dispersion processes through the formation, dissection and 37 preservation of landforms. It is based on the case study of sub Saharan West Africa, which recorded Neogene stepwise dissection of its topography through the emplacement of three lateritic pediment systems, which still occupy most of its surface. Pediments are erosional / transportation slopes having been weathered and duricrusted. Pediment-regolith

41 associations therefore depend on the parent rock, transport dynamics and preservation of 42 the material having transited on their surface as well as on the intensity of their weathering /

43 duricrusting. Iron oxy-hydroxide-cemented clastic sediments (detrital ferricretes) and 44 unconsolidated clastic sediments are the dominant outcropping material, and as such 45 represent a challenge for mineral exploration that relies on surface geochemical sampling to 46 detect metal concentration in the bedrock. Landform-regolith mapping beyond the scale of 47 modern interfluves combined with paleolandscape reconstitution are relevant to provide exploration guides for (i) interpreting geochemical anomalies on pediments, (ii) tracing their potential source when they have been "transported" on pediments and (iii) targeting

50 suspected ore bodies concealed beneath pediment(s). Past and present latitudinal climatic 
51 zonation of pedimentation and weathering patterns suggests a gradation of pedimentation

52 process across the intertropical zone and explains why pediments may have been

53 overlooked in equatorial environments, with implications for mineral exploration.

54 Successive pediment systems adapted to uneven, knickzone bearing river networks,

55 producing a spatially consistent and reduced $(<80 \mathrm{~m})$ stepping pattern of pediments

56 independent from elevation or position in the drainage. Pediments / pediplains are therefore

57 not proxies of uplift and their preservation over geological timescales typifies regions

58 submitted to less than $10 \mathrm{~m} /$ My erosion rates. The identification and study of lateritic

59 pediments bear important implications on shield sediment routing systems and a better

60 access to the bedrock and its resources, which may still be underestimated in the tropics.

61

62 keywords: Pediment; Regolith; Landform evolution processes; Mineral exploration; Mega-

63 geomorphology

64 preserved on its parental bedrock, regolith constitutes a weathering profile (Fig. 1), which et al., 2005). Once transported by slope or alluvial processes, regolith may act as a mask for

74 the underlying bedrock. As displaced regolith may undergo weathering after transport (Ollier 
76 is key for mineral exploration, which mostly relies on soil geochemical surveys (Butt et al.,

77 2000; Porto, 2016). Throughout the Cenozoic, shield surfaces outside the influence of

78 glaciers have primarily evolved by landscape dissection, the process by which paleolandscapes become isolated as relics overlooking younger active landforms as a result of slow and unevenly distributed erosion. Thereby, the relief of shields increases through

81 geological time (Thomas, 1989; Twidale, 1991), while landscape dissection is instrumental in exhuming regolith available to re-weathering and transportation. Therefore, the study of regolith distribution patterns over shield landscapes should not only provide exploration evolution processes and sediment delivery of very large cratonic river systems (Beauvais and Chardon, 2013; Grimaud et al., 2015, 2018).

Pediments are common landforms that typically form during, and contribute to, the process of landscape dissection, especially over vast non-orogenic regions of the world (e.g., Dohrenwend and Parsons, 2009). In the broadest sense of the term, pediments may be considered as gently inclined slopes of transportation and/or erosion that truncate bedrock and/or regolith and connect eroding slopes or scarps to areas of sediment deposition or alluvial transportation at lower levels (definition adapted from Oberlander, 1997). Pedimentation involves the physic-chemical processes that concur to form pediments. As transportation slopes feeding rivers with clastic sediments, pediments are a regulating element of the sediment routing system. As transit landsurfaces, pediments also carry transported regolith that masks the geological substrate. They are therefore an obstacle to mineral exploration (Payne, 1969; Pease, 2015) but have not been recognized as such in lateritic environments by exploration geologists and geochemists. Through the work of King $(1948,1967)$, the pediment concept also contributed to landscape evolution theories (Summerfield, 1991, pp. 457-467). However, no general agreement exists on the recognition 
101 criteria, regional correlation and the geomorphic meaning of paleo-pediments. Remaining

102 questions are (i) whether and how pediplains (i.e., regional surfaces of coalescent

103 pediments) can form and be preserved over geological time-scales ( $\left.10^{6}-10^{7} \mathrm{yr}\right)$ and (ii)

104 whether they may be gauges of continental deformation or whether they have another

105 geological signification (e.g., Tricart in Twidale, 1983; Summerfield, 1985, 1996; Thomas and

106 Summerfield, 1987; Twidale and Bourne, 2013; Dauteuil et al., 2015; Guillocheau et al., 2015, 107 2017).

Relationships amongst pediment development and preservation and regolith

109 production and remobilization are exceptionally exemplified over sub Saharan West Africa.

110 Pediment systems formed by stepwise dissection of the region West of $10^{\circ} \mathrm{E}$ and South of

$11120^{\circ} \mathrm{N}$ (Fig. 2) since the earliest Miocene (ca. $24 \mathrm{Ma}$ ) and still occupy an overwhelming part of

112 its surface. They exclusively expose lateritic regolith and are commonly capped by ferricrete

113 (a generic term used here for iron duricrust). The region hosts the southern West African

114 craton, which is an important metallogenic province (Milési et al., 1992; Markwitz et al., 2016)

115 and more specifically the largest Paleoproterozoic gold-producing region (Goldfarb et al.,

116 2017). The ubiquitous lateritic pediments of the region therefore pose an amazing

117 exploration challenge (e.g., Bamba, 2009). Building on decades of geomorphological

118 investigations throughout the sub region, recent progress made at dating, mapping and

119 regionally correlating lateritic pediments and earlier paleolandscape elements left by relief

120 dissection (Beauvais and Chardon, 2013) offered a new perspective for deciphering

121 denudation chronologies and landscape evolution processes on a sub-continental scale.

122 The present contribution is a review of the West African lateritic pediment systems

123 from the landscape to the sub continental scale. It addresses pediment landform-regolith

124 evolution processes to (i) evaluate the factors controlling the production and preservation of

125 pediments over geological timescales and their geological meaning, (ii) call attention to 
126 geochemical exploration pitfalls in lateritic pediment dominated environments and provide

127 adapted geomorphological exploration guides or strategies. The ubiquity of pediment-

128 dominated terrains in West Africa suggests that pediments occupy vast regions of the

129 tropical belt and calls for geomorphic reassessment of shield surfaces from both a

130 fundamental and applied perspective.

131

132 2. West African landscape-regolith evolution models for mineral exploration and the 133 recognition/study of pediments

134 The "landscape geochemistry" approach to tropical geomorphology has prevailed

135 for decades in the exploration and surface geochemistry communities (Butt, 2016).

136 Following Zeegers and Leprun (1979), such an approach led to pedogenetic geochemical

137 dispersion models elaborated for West African base metal deposits and various bedrock

138 lithologies that consider ferricretes as forming the upper residuum of weathering profiles

139 preserved on their parental bedrock (Butt and Zeegers, 1989; Zeegers and Lecomte, 1992;

140 Lecomte and Zeegers, 1992; Freyssinet, 1993; Bowell et al., 1996; Tardy, 1997; Fig 1).

141 Accordingly, ferricretes are inferred to display various degrees of geochemical dependency

142 on the underlying bedrock via the successive horizons of the weathering profile i.e., from

143 bottom to top: saprolite, mottled clays and carapace (Fig. 1). Within such a paradigm,

144 variations in concentration and mode of occurrence of base metals or other elements from

145 the bedrock to the ferricrete result from solute loss, vertical mass transfers and compaction

146 of the residuum as a sole consequence of lateritic weathering, leading to the formation of

147 geochemical dispersion halos (Roquin et al., 1990; Colin and Vieillard, 1991; Freyssinet, 1993;

148 Freyssinet et al., 2005; Fig. 3). West African exploration models consider cases where

149 weathering profiles were truncated by erosion and weathering horizons deeper than the

150 ferricrete are exposed or cases where such truncated profiles are overlain by unconsolidated 
151 colluviums (e.g., Bowell et al., 1996). But ferricretes are considered as formed from in-situ

152 regolith. A consequence of such popular landscape evolution models is that both the role of

153 pedimentation-driven relief dissection in redistributing regolith in the landscapes and

154 potential detrital origin of ferricretes have been overlooked for decades of mineral

155 exploration and geochemical investigations. However, among exploration geologists,

156 Bolster (1999) suggested that some West African ferricretes were detrital. More recently,

157 former advocates of the in-situ paradigm such as Butt and Bristow (2013) claimed that

158 ferricretes were "Fe oxydes-cemented sediments" and that "relief inversion [was] a very

159 widespread and important phenomenon" in West Africa (relief inversion being a case of relief

160 dissection that leads the lower part of an ancient landscape to become the highest part of

161 the new landscape; see Summerfield, 1991). Those findings were actually made 60 years ago

162 and documentation on those topics has accumulated since then from investigations by

163 geologists, soil scientists and geomorphologists.

164 Early geomorphological studies have shown that ferricretes occupying large surfaces

165 of the sub region contained gravels and cobbles of Al-Fe crusts, quartz and bedrock that had

166 no genetic relationships with their underlying saprolite or bedrock (Dresch, 1952a; Lamotte

167 and Rougerie, 1953, 1962; Pélissier and Rougerie, 1953; Daveau et al., 1962). In the meantime,

168 following reconnaissance by Pélissier and Rougerie (1953), Brammer (1955, 1956), Tricart et

169 al. (1957), Michel (1959) and Vogt (1959a) showed that these detrital ferricretes capped

170 generations of glacis - a French term for pediment(s). In his comprehensive geomorphic

171 investigation of the Senegambia drainage basin, Michel $(1959,1973,1974)$ deciphered and

172 mapped the sequence of lateritic pediments over Central and Northern Guinea,

173 Southwestern Mali and Senegal, (Fig. 2). More recently, glacis of Eastern Senegal and their

174 regolith were investigated through combined petrological and near-surface geophysical

175 investigations (electrical resistivity tomography and ground penetrating radar: Beauvais et 
al., 1999, 2004). The lateritic glacis of Senegal extend in southern and central Mauritania, but

177 they tend to be less iron-rich northward (Michel, 1977) and could even expose even

178 pedogenic calcretes (Nahon et al., 1977).

179

After Brückner (1955) and especially Hilton (1963) in Ghana (former Gold Coast), De

180 Swardt (1964) led the way for detailed investigations of the extensive lateritic pediment

181 systems of Nigeria that are correlated with the glacis sequence established in Guinea and

182 Senegal (Fölster, 1969a, 1969b; Rohdenburg, 1969; Burke and Durotoye, 1971; Fölster et al.,

183 1971; Fig. 2). Geomorphic description, petrological characterization and mapping of glacis

184 generations were undertaken over Burkina Faso (former Haute-Volta; Fig. 2) by Boulet (1970),

185 Eschenbrenner and Grandin (1970), Grandin (1976), Bamba (1996), Bamba et al. (2002) and

186 Grandin and Joly (2008). Works on glacis were also extended to the neighboring area of the

187 Republic of Niger by Mensching (1966) and Gavaud (1977). More recently, the mapping of the

188 glacis systems in Southwestern Burkina Faso by combinations of field surveys, airborne

189 geophysics and remote sensing was undertaken by Grimaud et al. (2015) and Metelka et al.

190 (2018).

191 In Côte d'Ivoire, intensive work was undertaken on glacis geomorphology and

192 weathering in the 1970s (e.g., Bonvallot and Boulangé, 1970; Eschenbrenner and Grandin,

193 1970; Boulangé et al., 1973; Grandin, 1976; Pèltre, 1977; see also Teeuw, 2002), whereas the

194 same glacis systems were reported in Sierra Leone (Fig. 2) by Grandin and Hayward (1975)

195 and studied by Thomas $(1980,1994)$, Thomas and Thorp $(1985)$, Bowden $(1987,1997)$ and

196 Teeuw (1987), although the two later authors did not explicitly refer to pediments, but to

197 "footslope laterites (duricrust)" (e.g., Bowden, 1987). Reconnaissance by Dresch (1952b)

198 indicates that the ferricrete-capped pediments of Niger and Burkina Faso extend over Benin

199 (as confirmed by our field observations) as well as in Togo (Fig. 2), where they have been

200 described as such and studied by soil scientists (e.g., Le Cocq, 1986; Meyer, 1992). 
Regional typologies and systematics of glacis were defined in the seminal

monographs of Michel (1973) and Grandin (1976). Three successive glacis systems have been recognized, namely the High, Middle and Low glacis, stepwise landscape dissection being

204 documented as the key process having allowed the preservation of relict bauxitic, 205 Intermediate and pediment landforms of each generation (e.g., Grandin and Joly, 2008; see 206 also Beaudet and Coque, 1994; Gunnell, 2003). Weathering patterns of the glacis sequence 207 have been treated in the reviews of Tardy (1997) and Tardy and Roquin (1998). The pediment 208 sequence was incorporated by Burke and Gunnell (2008) into their model of the African 209 Surface, which encompasses the entire relief of the continent and would have been 210 generated by deformation and correlative erosion of a initially flat and low lying continent211 wide surface since the Cretaceous. Remnants of each West African glacis system have been 212 correlated and mapped regionally by combining regional field surveys, photointerpretation 213 and the available literature (e.g., Beauvais and Chardon, 2013; Grimaud et al., 2014, 2018).

214 The present work stems from the experience gained in the course of those regional

215 correlations and compilations as well as our own field experience in Benin, Burkina Faso,

216 Guinea, Côte d'Ivoire, Mali, Niger and Senegal (Fig. 2). By considering pediments and glacis in 217 the broadest sense of the definition given above, the two terms are used here 218 interchangeably.

220 3. Pediments in the West African morphoclimatic sequence

221 The West African landscape is the end product of the stepwise dissection of an old, 222 low relief topography called the African Surface (e.g., King, 1948; Boulangé and Millot, 1988; 223 Chardon et al., 2016). This old landscape is mantled by bauxitic duricrusts resulting from a 224 long period of intense weathering that culminated and ended in the Early and Middle Eocene 225 (Millot, 1970; Valeton, 1991; Colin et al., 2005; Chardon et al., 2006; Beauvais et al., 2008; 
226 Beauvais and Chardon, 2013). The African surface is now preserved mostly as bauxite-

227 capped mesas dominating the current landscape. The High, Middle and Low glacis mark the

228 last main dissection stages of the African Surface. Remnants of a massive, nodular or

229 pisolitic ferricrete-capped landscape found below bauxite relics and above the glacis have

230 been used to define an Intermediate Surface (Michel, 1959, 1973; Vogt, 1959a). Bauxitic

231 duricrusts of the African Surface and the ferricretes of the Intermediate Surface top thick (>

$23280 \mathrm{~m}$ ) weathering profiles that are preserved on their parental bedrock (Grandin, 1976;

233 Boulangé, 1984, 1986; Boulangé and Millot, 1988; Valeton, 1991).

234 Each glacis system in the West African sequence shows, in most cases, evidence for 235 duricrusting (or induration), and lateritic weathering, after its formation. Pediments/glacis

236 are the most conspicuous and common active landforms of dry or sub-humid regions of the

237 world (e.g., Dohrenwend and Parsons, 2009). The successive shifts from pedimentation to

238 lateritic weathering/duricrusting of the three glacis systems are indicative of repeated

239 transitions from semi-arid to seasonally contrasted wet tropical climate over West Africa

240 (Tricart et al., 1957; Michel, 1973; Grandin, 1976). Duricrusting took place during climate

241 shifts toward dryer conditions at the ends of humid weathering periods, before

242 abandonment and dissection of one glacis system and formation of a new one (Beauvais and

243 Chardon, 2013). Systematic Ar-Ar geochronology of K-Mn oxides (cryptomelane) from the

244 Mn-rich duricrust and weathering profile of each member of the West African landform-

245 regolith sequence allowed constraining their weathering and abandonment ages (Beauvais

246 et al., 2008; Beauvais and Chardon, 2013; Fig. 4). The African and Intermediate regolith-

247 landform associations yielded 59-45 and 29-24 Ma age groups, respectively. The High, Middle

248 and Low glacis weathered before abandonment at 18-11, 7-6 and around 3 Ma, respectively

249 (Fig. 4). Those age groups would therefore restrain the main pedimentation periods to 24-18,

250 11-7 and 6-3 Ma for the High, Middle and Low glacis, respectively (Fig. 4). Ages obtained on 
251 alunite and jarosite (Vasconcelos et al., 1994), although indicative of lesser weathering

252 intensities than cryptomelane, are compatible with the period of bauxite formation,

253 weathering of the Intermediate landscape until the latest Oligocene (24 Ma) and the 18-11

254 Ma period of High glacis weathering (Fig. 4).

255

256 4. Glacis landforms and landscape chronologies

257 4. 1. Type-landforms and their spatial arrangements

258 The three generations of West African glacis remnants are best distinguished on the

259 piedmonts of topographic massifs, which form up to hundreds of meters' high residual

260 reliefs that had not been leveled by pedimentation (Figs. 5 and $6 a$ ). Those massifs are

261 typically made of greenstone belt material (andesite, basalt, gabbro, volcano sedimentary

262 rocks) or early Mesozoic dolerite sills hosted by tabular sandstones and preserved from

263 erosion thanks to their capping bauxites and/or Intermediate duricrusts. Glacis are graded

264 upward-concave surfaces sloping away from the massifs (e.g., Grandin, 1976). The stepping

265 of successive glacis relics attests to the polycyclic nature of the landscapes due to renewed

266 periods of pedimentation (Fig. 6a). The uppermost portion of an early glacis (e.g., the High

267 glacis) is commonly eroded in such a way that a peripheral hollow separates the glacis

268 remnant from its upslope relict landscape (Fig. 6a and 7a; e.g., Beauvais et al., 1999). A later

269 glacis (e.g., the Middle glacis) may shape the inner slopes of the peripheral hollow so that it

270 can reach a higher elevation than the relics of the earlier glacis (Fig. 6a). Relative elevation

271 alone is therefore not a reliable criterion to decipher glacis generations given their slopes

272 and their dissection patterns. Careful investigation of the relative geomorphic position,

273 lateral extension and age of landscape elements should therefore be preferred to establish a

274 glacis landscape chronology. 
Massifs to which piedmont glacis are connected may be eroded by headward river erosion so that only an inselberg (i.e., a rocky topographic massif stripped from its regolith) remains as a relic of the former bauxitic / Intermediate topography. Such an inselberg may have a lower elevation than the piedmont glacis relicts (Fig. 7) and in many instances erosion may even totally erase the massif to which glacis were connected. Likewise, glacis relict

280 surfaces carrying cobbles or boulders of bauxites are commonly preserved in areas where no 281 bauxite massifs remain (Bamba, 1996; Fig 7). River valleys connected upstream to peripheral hollows generally have a lower slope gradient than the early (High) glacis (Fig. 7b). Later (Middle or Low) glacis settle on their valley sides (Fig. 7b) that dip at a high angle to the earlier glacis slope direction. This implies that slope direction - and therefore surface material transport direction on the pediment - not only varies spatially for a given glacis generation (for instance for the High glacis radiating around a residual topographic massif) it varies also from one glacis generation to the next. multi-convexo-concave plain that is occupied by undulating glacis encompassing the entire 290 relief i.e., from the top of smooth convex interfluves to the lower part of their concave slopes 291 (Fig. 6b). Following Rohdenburg (1969) in his review of Southern Nigerian pediment systems, 292 the term of rolling pediplain is used here to describe such glacis landscape regions (see also 293 Fölster, 1969a). They have 2 to $20 \mathrm{~km}$ wavelength and modest (<30 m) amplitude and may 294 preserve a relict - and often dismantled - ferricrete inherited from a former glacis surface on 295 their interfluves (called, in this case, residual hills) (Fig. 6b). Rolling pediplains are by far the 296 most common regional landform associations in today's West Africa and are locally studded 297 with relict glacis plateaus of limited extent that were not reduced to residual hills. They are 298 mostly inherited from past glacis landscape stages. Middle glacis pediplains (Fig. 6b) are the 299 best preserved in today's landforms although the downslope portions of such 
300 paleolandscapes are generally re-cut by the Low glacis (e.g., Fig. 6b). Regional correlations of

301 glacis systems chronology may be deciphered along 10-100 km long transects going from

302 piedmont contexts - where the pediment stepping pattern is well defined - to rolling

303 pediplain contexts. Field investigations restricted to the scale of an interfluve or a few

304 interfluves are indeed not sufficient to elaborate a landscape chronology given the lateral

305 variability of the paleolandforms preservation patterns (see section 6.2).

306

307

\section{2. Relief dissection patterns}

Repeated relief dissection favored the stepping of successive glacis in piedmont

309 contexts (Figs. 8a and 8b). The relative elevation between successive glacis does not

310 systematically decrease downslope i.e. away from the residual massif (Fig. 8a) contrary to

311 the common slope evolution models (e.g., Summerfield, 1991, pp. 457-467). It may increase

312 downslope toward the main drainage axes (Grandin and Joly, 2008; Fig. 8b). The dissection

313 of rolling pediplains leads to more complex stepping patterns owing to whether erosion

314 focused on residual hills or valleys from one glacis landscape stage to the next (Figs. 8c to 8e).

315 Inselbergs are locally preserved on granitoid terrains. They seem to have formed by a

316 combination of geological factors among which rock structural control, the original relief of

317 an old and thick weathering profile and the polycyclic denudation history are the most

318 important (Thomas, 1978, 1994).

319 In case where a glacis is not strictly stepped into an older glacis, mostly as a

320 consequence of limited base-level fall (i.e., river down-cutting) during its development, a

321 composite (i.e., polygenic) landsurface forms. Slight oblique leveling of the early glacis up to

322 a certain elevation by the younger glacis may lead to a more or less expressed change of

323 slope in that landsurface (Fig. 6). Polygenic development is also mostly expressed in the

324 downslope parts of two successive glacis that merge into a single graded (and often 
325 functional) surface, whereas they are stepped higher up in the landscape (e.g., Fig. 6a).

326 Polygenic High/Middle glacis are observed but the most common cases of polygenic developments are between the Middle and Low glacis, particularly in dry regions (Boulet, 1970; Eschenbrenner and Grandin, 1970). In the Sahelian zone (Fig. 2) where base-level fall

329 has been limited between the Intermediate Surface and the High glacis approaching the 330 Niger River (e.g. Grimaud et al., 2014), polygenic glacis development is common between these two landscape systems (see also Fig. 5).

Relief dissection and denudation did not allow a good preservation of High glacis stage rolling pediplains of significant regional extent with the exception of specific areas of

334 flat sandstones. Those rolling pediplains generally have longer (>10 km) wavelength than 335 those of the Middle glacis. Low glacis pedimentation did not produce rolling pediplains.

336 From the Soudanian zone southward (Fig. 2), Low glacis systems mostly contributed to re-

337 cut or straighten downslope portions of Middle glacis landscapes (often producing a

338 polygenic surface). Further north, the Low glacis system largely developed and is still

339 functional (see below).

\section{3. Sequential landscape development}

The High glacis pedimentation period has produced a multi-concave pediplain over

343 granite-greenstone terrains or dolerite sills provinces. The pediplain was studded with

344 relictual reliefs inherited from the bauxitic and/or the Intermediate landscape stages

345 (Grimaud et al., 2015; Figs. 7 and 9). In other geological provinces, the High glacis landscape 346 consisted in a rolling pediplain of long (>10 km) wavelength (e.g., Fig. 8c). Middle and Low 347 glacis pedimentation cycles generally formed narrower valleys than those of the High glacis 348 landscape (e.g., Figs. 8d and 8e), especially within and south of the Soudanian zone (Fig. 2). 349 Figure 10 summarizes the sequential development of a type West African landscape. Each of 
350 the successive landscape stages incorporates relict landforms of various earlier generations.

351 It is a composite landsurface comprising inselbergs (not shown on the Figure), relics of the

352 bauxitic and/or Intermediate landscapes and former glacis (Fig. 10). The Middle and Low

353 glacis landscape stages therefore integrate increasing complexity compared to earlier

354 landscapes. This is explained by a decreasing pedimentation efficiency manifested by

355 generally narrower glacis widths and would be consistent with the decreasing duration of

356 pedimentation periods through time i.e., 6, 4 and 1 My for the High, Middle and Low glacis,

357 respectively (Beauvais and Chardon, 2013). Relics of the entire West African paleolandscape

358 sequence are not always preserved on a 10-100 km scale (Fig. 10). Besides an evolving

359 drainage density, landscape stages succession implies slope direction changes or reversals

360 (Fig. 10), with implication for material transit patterns on glacis slopes through time (section

361 7.2).

Multi-concave pediplains are mostly restricted to granite-greenstone terrains or

363 areas of mafic substrate owing to iron-rich lithologies, which are more alterable than felsic

364 rocks. They tend therefore to produce thick and massive duricrusts, which have a protective

365 effect once the landscape they cap is submitted to dissection. The development of piedmont

366 glacis is favored below scarp-bounded relict paleolandscapes, the scarp being armored by

367 the ferricrete. In such contexts, glacis are also prone to dissection because their capping

368 ferricretes are mostly cemented debris of Al-Fe crusts inherited from the older, inverted

369 landsurfaces and are therefore iron-rich and resistant even though they are not underlain by

370 mafic rocks (see section 5). Over iron-poor lithologies and away from mafic sources, both the

371 lower iron content and thickness of the duricrusts reduce their strength. Pedimentation is

372 therefore more efficient at leveling interfluves to produce rolling pediplains and no strict

373 relief inversion takes place. 
Notwithstanding the regional spatial variability of the glacis stepping patterns described above, each glacis system has type-geomorphic characteristics that may be summarized as follows (Grandin and Joly, 2008). Relics of the High glacis are abandoned as plateaus or residual hills that rarely occupy more than $20 \%$ of the current landsurface over

$380100 \times 100 \mathrm{~km}$ areas. They can attain heights of more than $100 \mathrm{~m}$ above the local base level for 381 the upslope portion of very large relics and not more than $30 \mathrm{~m}$ for their lowermost portions along the main drainage axes. Middle glacis are generally eroded downslope and are still connected to their upslope reliefs. They are preserved as low plateaus or relictual hills in dry

384 regions (Fig. 2), where the Low glacis developed at their expense. Large Middle glacis

385 remnants may still be functional i.e., currently subjected to runoff and sediment transport.

386 Low glacis occupy a large part of the landsurface and are still functional in dry climatic zones, 387 where they are connected to the local base level. Elsewhere, river alluviums usually mask the 388 incision of Low glacis of a few meters. Excavation of the Bauxitic African Surface varies from ca. $500 \mathrm{~m}$ in central Côte 390 d'Ivoire to less than 30 m near the Niger River in Central Mali, with a mean value around 300 391 m (Beauvais and Chardon, 2013; Grimaud et al., 2014; Fig. 2). Incision of the High glacis is 392 typically of 50-80 m, whereas the High glacis pedimentation period contributed to $40-130 \mathrm{~m}$ 393 of incision of the Intermediate landscape (Grimaud et al., 2018). The three pedimentation 394 cycles therefore contributed as much excavation of the African bauxitic Surface $(90-210 \mathrm{~m})$ 395 as the Intermediate period of erosion (75-200 m; Grimaud et al., 2018) over comparable time 396 spans of 22-24 My (Fig. 2), leading to a long-term denudation rate of 3-9 m/My.

397 Pedimentation efficiency decreased over the Neogene in West Africa. Given the glacis widths 398 and ages in the Guinean and Soudanian zones (Grimaud et al., 2015; Fig. 2), lateral growth 399 rate ranges of glacis would typically be of $0.75-3 \mathrm{~km} / \mathrm{My}$ and $0.15-1 \mathrm{~km} / \mathrm{My}$ for the High and 
400 Middle glacis system, respectively. Given its restricted development in the same climatic

402 those of the Plio-Quaternary Southwestern United States' pediments $(0.03-0.36 \mathrm{~km} / \mathrm{My}$;

403 Dohrenwend and Parsons, 2009).

404

405 5. Glacis regolith and weathering patterns

406 Similarly to pedimentation efficiency, the intensity of weathering and duricrusting of

407 the glacis decreases generally from the High to the Low glacis (Boulangé et al., 1973; Grandin,

408 1976; Tardy and Roquin, 1998). This decrease is consistent with long-term Neogene climate

409 cooling and the progressively shorter duration of humid periods required for the weathering

410 of the glacis material (Beauvais et al., 2008; Beauvais and Chardon, 2013; Fig. 4). The spatial

411 and temporal variability in the nature of glacis surfaces and regolith (Fig. 11) is further

412 controlled by the interplay of three main factors, which are (i) the nature of the substrate cut

413 by pedimentation, (ii) the nature, transport dynamics and degree of preservation of clastic

414 sedimentary material that has been transiting on the glacis and (iii) the nature and intensity

415 of weathering and duricrusting undergone by the glacis after their formation. Figures 12 to

41614 illustrate field examples of the main types of glacis regolith / ferricretes and Figure 15

417 represents various types of regolith associations on glacis. A synthetic model of the relations

418 between pedimentation and weathering is provided in Figure 16.

420 5. 1. Conglomeratic regolith, ferricrete and slope processes

421 Remarkable and common glacis ferricretes derive from cementation of

422 conglomeratic material transiting on the glacis surface. The most spectacular ones are

423 matrix- or block supported debris flows. Depending on the landscape having been stripped

424 off and the pedimentation regime, conglomerates' elements range from gravel to boulder 
425 and consist of bauxite, Intermediate ferricrete, earlier glacis ferricrete, iron oxy-hydroxide

426 nodules and/or quartz debris (Figs. 12b to 12e). Conglomerates' matrixes comprise reworked

427 weathering profile materials ranging from clays to sands (former saprolite) and gravels made

428 of ferruginous nodules and quartz debris. Apart from quartz, the occurrence of fresh bedrock

429 clasts in debris flows is extremely rare, indicating that mostly regolith was stripped-off

430 and/or submitted to landsliding to produce debris flows. When present in glacis transported

431 regolith, bedrock clasts are almost always highly ferruginized to the point of being a massive

432 ferricrete preserving bedrock structures such as schistosity. Such ferricretes are typical of

433 the Intermediate weathering profile (Fig. 12d).

$434 \quad$ Lower-slope alluvial sedimentary facies are also common, especially in the

435 downslope parts of glacis, even though ferruginization contributed to alter sedimentary

436 structures in glacis alluviums such as parallel and oblique stratifications and cross beds. The

437 occurrence of rounded quartz pebbles in the most distal parts of glacis near river drains

438 indicates that glacis pass downslope to alluvial terraces (the "glacis-terrasse" concept of

439 Michel $(1959,1973)$ and Vogt (1959a)). Erosional unconformities and disconformities at the

440 base or within the glacis sedimentary cover are consistent features of truncation and

441 deposition by channelized to sheet flow down the glacis slopes. The most obvious (and best

442 preserved) alluvial features are channels identifiable along the basal erosional surface of the

443 glacis sedimentary layer (Fig. 12f). Beddings are also observed as separating successive

444 debris flows or within sedimentary units.

445 Sedimentary patterns vary spatially from coarse flows to braided channels at the

446 scale of single large glacis relics. This indicates space-time interplay of debris flows and

447 sheet floods comparable to those observed on Quaternary or functional alluvial fans and

448 pediments of arid or semi-arid regions of the world (Bull, 1977; Oberlander, 1997;

449 Dohrenwend and Parsons, 2009). Besides, functional glacis in the Soudanian and Sahelian 
450 zones (Fig. 2) provide an actualistic perspective onto the sedimentary patterns and

451 alluvial/colluvial processes having operated on the past West African glacis before

452 duricrusting (Grandin and Joly, 2008). Water and sediment transport modes on glacis

453 precluded the maintenance of ramified river networks but instead favored dense and

454 unstable channel networks that were active only during rainy episodes. Rivers maintained

455 their courses only at the downslope junctions of converging glacis, where alluvial

456 sedimentary facies can be found (e.g., Figs. 8, 9 and 10).

457 Glacis conglomeratic ferricretes are usually underlain by a carapace and/or a

458 mottled clays horizon (Fig. 15a), implying that duricrusting is confined to the conglomeratic

459 layer. In other cases, thick conglomeratic covers are duricrusted only superficially, meaning

460 that part of their thickness became a carapace. Glacis conglomeratic overburdens are not

461 necessarily cemented (Fig. 12a), allowing to access original sedimentary textures that have

462 not been obscured by iron segregation and cementation. The conglomerates and their

463 matrixes consist almost exclusively of reworked Al-Fe duricrusts, carapace, mottled clays

464 and saprolite, which are all rich in iron oxy-hydroxides. Large quantities of iron are therefore

465 available in the conglomerates. Remobilization of that iron should favor cementation of the

466 glacis sedimentary overburden by oxy-hydroxides to form ferricretes. Such cementation

467 scenarios are attested to by the common examples of glacis ferricretes directly overlying

468 fresh bedrock. This shows that ferricretes do not result from the sole relative accumulation

469 of iron in a horizon of the weathering profile having successively gone through bedrock,

470 saprolite, mottled clays and carapace stages. In other words, lateritic weathering is not a

471 necessary condition for duricrusting (Grandin, 2008).

473 5. 2. Non-conglomeratic ferricretes, relationships with the underlying regolith 
Some glacis ferricretes are composite, comprising an upper conglomeratic layer and

475 a lower layer that results from iron aggradation/segregation and induration of the underlying carapace (Figs. 13 and 15b). In this case, duricrusting appears to have taken place

477 beyond the base of the sedimentary overburden and the relative contributions of in-situ iron 478 accumulation (from segregation within the carapace) and absolute iron input from the 479 clastic sediments would be difficult to assess. Conglomeratic ferricretes are also seen to rest 480 directly atop a saprolite or a saprock (i.e., basal core stone-bearing saprolite; e.g., Figs. 12b,

$48112 \mathrm{f}$ and $15 \mathrm{c}$ ) or even the bedrock. This indicates that pedimentation truncated a weathering 482 profile by removing its mottled clays, carapace or part or the entire thickness of its saprolite. 483 Those truncations are currently seen in the field and have been also imaged by geophysics 484 (e.g., Beauvais et al., 2003). The formation of iron nodules and/or iron segregation may be 485 observed immediately under the conglomerate in the truncated weathering profile, 486 indicating that ferruginization was not restrained to the transported sedimentary layer and 487 that iron originated from the conglomeratic cover. Whether the weathering horizons 488 underlying a conglomeratic ferricrete developed onto a preexisting saprolite or from pristine 489 weathering of bedrock exhumed by pedimentation would be difficult to assess in the field. $490 \quad$ Glacis ferricretes developed from fine-grained material (clay, silt, sand or a mix of 491 those) have vermicular to nodular structures (Fig. 14) typically resulting from the maturation 492 of mottled clays by iron concretion/segregation (Tardy, 1997; Fig. 15d). Those ferricretes are 493 preferentially found on the distal parts of wide glacis and are ubiquitous in rolling pediplain 494 contexts i.e., on lower-gradient slopes than the debris flows, which are mostly restricted to 495 piedmont contexts. In conglomeratic ferricretes, matrixes are vermicular, as is the 496 duricrusted material underlying conglomeratic layers of composite ferricretes (e.g., Fig. 13). 497 If a comprehensive succession of weathering horizons exists under the vermiform/nodular 498 ferricrete down to the bedrock, the glacis surface could be considered as erosional, and the 
499 ferricrete as genetically linked to the underlying bedrock (e.g., Fig. 15d). But weathering of a

500 composite section made of bedrock and/or saprolite topped by a fine-grained glacis

501 overburden would end up producing a comparable profile (Fig. 15e). Fine-grained

502 overburdens being mostly reworked saprolite, it would be difficult to locate the boundary

503 between the in-situ and transported portions of the section, which would have been further

504 obscured by weathering after pedimentation, unless a major break in lithology or

505 granulometry be identified (Fig. 15e). The very large areas of functional glacis exposing

506 alluviums composed of clays, silts and sands suggest analog fine-grained overburdens for

507 past glacis systems. Weathering/duricrusting of such overburdens should end up forming a

508 typical vermicular / nodular ferricrete that may top weathering horizons mimicking those

509 produced on bedrock (e.g., Fig. 13). Most weathering profiles of West African ferricrete-

510 capped glacis weathering profiles may therefore be composed of fine-grained transported

511 material instead of resulting from weathering of bedrock even though the ferricrete is not

512 conglomeratic.

513 There is commonly a spatial variability in the nature of the surface at the scale of a

514 single glacis that comprises ferricrete-free surface areas and (erosional or detrital) ferricrete-

515 capped surface areas (Fig. 11). In other words, the detrital layer does not systematically

516 cover an entire glacis and duricrusting does not necessarily affect an entire glacis surface.

517 Ferricrete-free glacis surfaces may be erosional and expose exhumed regolith developed

518 from bedrock (Fig. 15f). However, the possibility that they actually expose transported (fine-

519 grained) saprolite that escaped duricrusting is not precluded (Fig. 15g). In this case, only a

520 detailed petro-geochemical investigation would allow distinguishing an in-situ saprolite

521 from an overlying transported layer.

522 Contrary to the inselbergs and residual massifs they contributed to exhume, West

523 African glacis do not expose bedrock but regolith. This could suggest that weathering has 
524 turned bedrock leveled by pedimentation into regolith. But observations along river cuts

525 and in trenches indicate that glacis are essentially cut into a saprolite previously formed

526 during an earlier weathering period (e.g., Figs. 11, 12b and 15). Observations of the steep

527 stripped flanks of bauxite plateaus of dry regions show that the relief carved into the bauxitic

528 surface by the glacis is entirely made of saprolite more than $40 \mathrm{~m}$ thick (e.g., Fig. 6a). With

529 the exception of inselbergs, the lower flanks of residual massifs and low-lying outcrops

530 exhumed after abandonment of the Low glacis, bedrock is mostly exposed in riverbeds.

531 The ubiquity of glacis systems throughout West Africa is explained by the fact that they were 532 easily cut through regolith instead of bedrock, as also shown for the pediments of Central

533 Australia by Mabbutt (1966). Most of the regolith thickness available for stripping by

534 pedimentation was likely produced by the Bauxitic (and Intermediate) periods(s) of intense

535 lateritic weathering (Grimaud et al., 2015). The thin $(<20 \mathrm{~m})$ weathering profiles genetically

536 linked to each glacis would suggest that weathering phases following pedimentation periods

537 produced a regolith layer available for stripping during the next pedimentation period (e.g.,

538 Millot, 1980). This hypothesis would apply to the lowermost parts of glacis cut into bedrock

539 (e.g., cross-section, Fig. 15) and would be supported by the comparable heights of the

540 weathering profile and the vertical separation between successive glacis.

$541 \quad$ Notwithstanding the spatial variability in the nature of individual glacis surfaces and

542 associated regolith, main type-characteristics of ferricretes and weathering patterns of each

543 glacis system may be synthetized as follows (Grandin, 2008). The High glacis ferricrete can

544 reach $10 \mathrm{~m}$ in thickness in piedmont contexts and the underlying weathering profile rarely

545 exceeds $20 \mathrm{~m}$. Middle glacis ferricretes do not exceed $5 \mathrm{~m}$ and are generally limited to 1 to 2

$546 \mathrm{~m}$. Their underlying weathering profile is reduced to a few meters and is not as kaolinite rich

547 as that of the High glacis. Ferricretes of functional Middle glacis often show evidence for

548 dissolution and end up acquiring vacuolar to cavernous textures (Leprun, 1979). The Low 
549 glacis bear a thin $(<1 \mathrm{~m})$ ferricrete or, more generally, at best a carapace. Carbonate

550 concretions may develop under its erosional surface or in its sedimentary overburden and

551 neo-formed clays are mostly smectites.

552

\section{5. 3. Recently remobilized regolith and alluviums}

$554 \quad$ Low glacis are commonly overlain by unconsolidated alluvial and aeolian sediments

555 (Fig. 15h), which are actively reworked by pedimentation during each rainy season

556 (especially in the Soudanian and Sahelian zones; Fig. 2). It is also the case for large functional

557 Middle glacis. Active alluvial fans also occupy upslope sections of functional glacis in

558 piedmont contexts, at least in the dry zones (e.g., Fig. 5). Streams that have incised the glacis

559 sedimentary overburden generally flow atop the ferricrete or the carapace and expose

560 sections that commonly exceed $2 \mathrm{~m}$ in thickness. Overburdens occupy huge areas and

561 develop soils that are exploited for agriculture. But those soils almost never derive from

562 weathering profiles connected to the underlying bedrock because they are transported and

563 almost always overly conglomeratic ferricretes (Fig. 15h).

564 Post-Low glacis (i.e., Quaternary) river alluviums are preserved along the drainage

565 network and often correlate with the unconsolidated glacis cover (Fig. 11; Fig. 15, upper

566 cross-section). The oldest and most remarkable alluvial terrace of regional extent has been

567 reported and correlated from the main rivers of Northern Guinea, Senegal, Southwestern

568 Mali, Ivory Coast and Burkina Faso (Vogt, 1959a, 1959b; Michel, 1969, 1973; Eschenbrenner

569 and Grandin, 1970; Grandin, 1976). This terrace is floored by a cemented conglomerate (the

570 "graviers sous-berge") that occupies the riverbeds and has been incised of less than a few

571 meters (Fig. 15). Aggradation/incision cycles younger than the conglomerate have been

572 recognized but no systematic regional patterns have been deciphered yet (Thomas and 
573 Thorpe, 1985; Hall et al., 1985; Thomas et al., 1985; Teeuw et al., 1991; Ouangrawa et al., 574 2000).

575

\section{6. Extent and variability of the glacis record in West Africa}

\section{6.1. Geomorphic provinces and areal extent of glacis}

578 The compilation of a regional landform-regolith map (Fig. 17) shows that the relics of

579 the three glacis systems occupy an overwhelming areal proportion of the landsurface, with

580 the exception of a few regions of specific geological substrate, topography or active

581 sedimentation. Laterally continuous bauxite-capped landforms of the African Surface form

582 mappable units restrained to some highly-elevated $(>500 \mathrm{~m})$ areas of Pre-Cenozoic

583 sandstones and/or high concentration of dolerite sills (Fig. 17). Paleolandscapes capped by

584 the Intermediate ferricrete are well preserved on Cenozoic sedimentary basins and their

585 margins, as well as on Pre-Cenozoic tabular sandstones flanked by rock escarpments (Fig. 586 17).

587 The Archean and Paleoproterozoic granite-greenstone terrains, their adjoining

588 mobile belts and the remaining tabular sediments of the sub-Saharan area are characterized

589 by glacis composite landscapes (Fig. 17) such as those illustrated on Figures 5- 8, 10 and 15.

590 In those landscapes, the High glacis system always occurs as relict plateaus or hills. Distant

591 relict massifs of the Bauxitic and/or Intermediate landscape and inselbergs remain (e.g., Fig.

592 6a). A large part of the composite glacis landscape geomorphic province is a Middle-Low

593 glacis rolling pediplain locally preserving High glacis remnants as interfluves (e.g., Figs. 6b).

594 The relative extent of the Low glacis system tends to grow northward going across the

595 Soudanian zone to become maximal in the Sahelian zone where a Low glacis province is

596 defined (Figs. 1 and 17b) as a vast and very flat pediplain with tens of kilometers-wide glacis

597 that are functional. The efficiency of pedimentation is favored by both the Sahelian climate 
598 and the limited $(<40 \mathrm{~m})$ local relief left since the abandonment of the bauxitic African

599 surface along the considered portion of the Niger River Valley (Grimaud et al., 2014; Chardon 600 et al., 2016).

601 In the Saharan zone (Figs. 1 and 17b), low lands consist of active regs, dune fields

602 (ergs) and fluvio-aeolian sandplains that mostly blanket the subdued Intermediate or Low

603 glacis landscapes, whilst crystalline substrate generally crops out. South of the Sahelian

604 zone, bedrock is exposed mostly on the steep dissected slopes of regional topographic

605 massifs upon basement substrate (Figs. 1 and 17).

606 The bauxitic African Surface was an etchplain i.e., a low-relief continental scale

607 landsurface underlain by a thick regolith resulting from a protracted period of intense

608 weathering and correlatively subdued mechanical erosion. As a result of stepwise dissection

609 of that landsurface by pedimentation, most of its regolith mantle has been removed so that

610 sub Saharan West Africa has become a stripped etchplain, whose remnants are preserved

611 only in a few patches of relict bauxitic landscapes (Fig. 17) and individual occurrences

612 scattered over the sub region (Beauvais and Chardon, 2013; Chardon et al., 2016). The glacis

613 composite landscape province (Fig. 17) constitutes the stripped African etchplain.

614

615 6. 2. Climatic zonation of paleo-glacis systems and glacis degradation processes

616 The preservation of each glacis system depends on (i) the efficiency of planation (i.e.,

617 the capacity of pedimentation to form wide glacis), (ii) the intensity of duricrusting and (iii)

618 the magnitude of glacis dismantling (Grandin, 1976). Those three factors are chiefly

619 dependent on latitude (Fig. 18). Their spatial variations from one glacis system to the next

620 could suggest an evolving latitudinal climatic zonation of West Africa over the last ca. $25 \mathrm{Ma}$

621 notwithstanding the duration of each glacis cycle (Fig. 18). 
623 molded their pristine shape and pedimentation-driven landscape dissection leads to

624 plateaus with sharp edges. On-going pedimentation can eventually turn the plateau into a

625 residual hill (Fig. 19a) flanked by concave glacis slopes. Weathering is subdued during this

626 process and mechanical dismantling of the ferricrete takes place while pedimentation

627 disperses its erosional products downslope. Such a morphogenesis typically produces

628 rolling pediplains (Fig. 6b). In zones of intense pedimentation, residual hills are ultimately

629 erased to produce very low amplitude pediplains made of wide glacis. Under humid climates,

630 and typically in the forest, weathering assists degradation of the plateau-flanking slopes that

631 evolve by a combination of compaction of the residuum, creep and colluvial processes to

632 acquire convex profiles, while the ferricrete is being dissolved and dismantled and collapses

633 onto its underlying weathering profile that is reactivated (Fig. 19b). The combination of

634 those processes produces a common type of stone line i.e., a layer of angular or sub-

635 rounded quartz gravels and pebbles, which result from the dislocation of quartz veins by

636 compaction. The resulting residual hills are "demi-oranges" (Thomas, 1994) that form

637 multiconvex plains typical of today's shields' tropical rain forest (e.g., Rohdenburg, 1982;

638 Lecomte, 1988; Bitom et al., 2004).

639 Recent morphogenesis (i.e., having taken place after duricrusting of the Low glacis

640 around $3 \mathrm{Ma}$ ago) tends to degrade relict High and Middle glacis. Semi-arid climates of the

641 Sahelian and southern Saharan zones favor the development of very flat pediplains, whereas

642 the sub-equatorial humid climate of the Forest zone drives degradation of glacis to form

643 multi-convex plains. A latitudinal gradient must exist between these two modes of modern

644 morphogenesis across the Soudanian and especially the Guinean zones (Grandin, 1976; Figs.

6451 and 17). A somewhat comparable latitudinal morphoclimatic gradient applied to each

646 paleo-glacis system, although with potentially contrasted climatic zone widths (Fig. 18). 
647 Such a gradient explains systematic limited planation and duricrusting in the South (Fig. 18),

\section{3. Morphoclimatic specificity of West Africa, comparison with neighboring regions}

The remarkable preservation of the West African glacis systems is related to the sub

661 latitudinal stability is due to the pinning down of the African plate's rotation pole near the

662 Coast of Guinea (Tardy and Roquin, 1998). Optimal duricrusting worked in two ways for the 663 preservation of glacis. First, weathering/duricrusting produced a major original stock of iron

664 during the bauxitic weathering period i.e., from the Late Cretaceous to the mid Eocene (with 665 a peak between 55 and $45 \mathrm{Ma}$ ). This original iron stock was then recycled in the Intermediate 666 landscape and by each glacis system (Grandin, 1976). Second, optimal conditions favored 667 duricrusting of Al-Fe crust dispersed on glacis to form protective duricrusts that favored 668 landscape dissection and paleo-glacis preservation.

669 Regions located further to the East and encompassing the same current latitudinal 670 band as sub Saharan West Africa have undergone a greater northward shift across the inter 671 tropical zone (and beyond) since the Late Cretaceous that likely resulted in a contrasted 
672 morphoclimatic record. Nevertheless, those regions preserve a record of stepped pediment

673 systems that may correlate with those of West Africa (e.g., Fölster, 1964). A "High" glacis

674 system has been reported regionally under what appears as the remnants of the

675 Intermediate ferricrete-capped paleolandscape (De Swardt, 1964; McFarlane, 1976, and

676 references therein) but no systematic correlation scheme has emerged yet. Further South in

677 Central Africa, pediment systems occupy large regions around and within the Congo Basin

678 (Ruhe, 1956; Guillocheau et al., 2015). The latter authors proposed a tentative correlation

679 between their 9-planation surfaces model (among which the 5 latest are pediment systems)

680 and the West African morphoclimatic sequence as synthetized by Beauvais and Chardon

681 (2013). Degradation of glacis systems in Equatorial Africa under perhumid climates would be 682 a challenge for regional morphoclimatic correlation across the intertropical belt.

683

\section{$684 \quad 7$. Implications for mineral exploration}

685

The great extent and spatial variability of the West African glacis landform-regolith

686

associations (Fig. 17) prompt caution when targeting suitable spots for surface sampling that

687 would reflect bedrock geochemistry as accurately as possible. Glacis regolith profiles are

688 indeed composite and polycyclic, resulting from uneven weathering and duricrusting of

689 slopes cut into a pre-existing regolith and/or the bedrock and overlain by discontinuous

690 detrital sedimentary layers.

691

692 7.1. Accessibility to the geological substrate

693 Glacis ferricretes all represent an obstacle to access bedrock geochemistry. There

694 are three main reasons for this. First, they often represent sedimentary covers that are

695 allochtonous (Figs. 15a-15c, 15e) and do not derive from their underlying regolith by

696 weathering. Second, even if formed exclusively in-situ, and as the most evolved product of 
697 weathering, ferricretes would have lost most of the geochemical characteristics of the

698 bedrock (e.g., Tardy et al., 1988; Boeglin and Mazaltarim, 1989; Roquin et al., 1990). Third,

699 solute elemental transfers through the regolith and sedimentary cover down the glacis slope

700 can contribute to absolute elemental accumulation in the ferricrete, especially in iron

701 (Maignien, 1958, 1966; Ollier and Galloway, 1990, Beauvais, 1999; Brown et al., 2003).

702 Therefore, vertical geochemical mass balances through ferricrete-capped glacis weathering

703 profiles are often misleading indicators of weathering-controlled dispersion of bedrock

704 elemental concentrations. Ferricrete-free glacis surfaces pose another sizable exploration

705 issue. Only erosional portions of such surfaces would provide direct access to a saprolite

706 preserved on its parental bedrock (Fig. 15f), providing they are identified as such and not

707 mistaken for transported saprolite (Fig. 15g). Loose sedimentary glacis overburdens (Fig.

708 15h) mask their substrate. They are commonly thick (>2m), overly a detrital ferricrete and

709 may be mistaken for soils. It is why even sampling at $50 \mathrm{~cm}$ depth - as often undertaken in

710 such material - is not appropriate to attain the saprolite preserved on its parental bedrock.

711 Only sampling of the bedrock or the in-situ preserved saprolite is reliable for

712 characterizing the geological substrate's geochemistry (propitious locations would be edges

713 of glacis plateaus that expose weathering horizons under the ferricrete). In all other

714 situations, a surface geochemical anomaly on a glacis can have several meanings. In the best

715 case, the surface is erosional and ferricrete-free, the anomaly signing an underlying bedrock

716 concentration (e.g., Au, Pt, Zn, Cu). The present work however suggests that such

717 configuration is rarely demonstrated. In all other - most common - cases, the anomaly would

718 be ambiguous. It may have been "transported" with the sedimentary cover on the glacis by

719 pedimentation (e.g., Sanfo et al., 1992) or may be the expression of a potentially complex

720 and very wide dispersion halo having been elongated downslope. Such a halo could also at

721 least partly result from geochemical dispersion of a bedrock anomaly through a transported 
722 overburden by biological, gazeous or capillarity processes (Anand et al., 2014). Conversely,

723 the absence of a surface anomaly would not preclude the occurrence of an anomaly in the

724 underlying bedrock. In any case, landform-regolith mapping and establishment of a glacis

725 landscape chronology are required around the sampling sites in order to (i) constrain the

726 geomorphological context of the anomaly for locating its potential distant source or (ii)

727 identify glacis covers that mask potential bedrock resource(s) (Bamba, 2009).

728

\section{2. Geomorphological exploration guides}

Gold anomalies in detrital glacis ferricretes overlying barren bedrock are common.

731 Studies combining detailed landform-regolith mapping, trench studies, geochemistry and

732 gold particles characterization allowed documenting km-scale downslope displacement of

733 gold particles from their bedrock sources (Sanfo et al., 1992, 1993; Parisot et al., 1995;

734 Ouangrawa et al., 1996; Bamba et al., 2002). For such investigations cannot be undertaken

735 systematically, the geomorphological approach may prove rewarding in constraining the

736 potential bedrock source area of a transported anomaly based on the assumption that it has

737 been displaced down the slopes of a considered glacis.

738 In rolling pediplain contexts, tracing the potential upslope source of a transported

739 anomaly should be straightforward, providing the glacis landscape has not been

740 significantly dissected and preserved its original interfluve (e.g., Figs. 6b and 6c-6e). In such a

741 case, the source of the transported particles cannot be located beyond the preserved glacis

742 interfluve. In dissected rolling pediplains and particularly piedmont contexts, upslope

743 portions of glacis are rarely preserved (e.g., Figs. 6a; 7; 10). Paleolandscape reconstruction at

744 the time the sampled glacis was functional is necessary to evaluate the potential path

745 followed by the glacis sedimentary cover during pedimentation. Instead of a cross-sectional 746 approach, a three-dimensional landscape reconstruction (e.g., Fig. 7) is suitable to take into 
747 account the entire upslope drainage area that could have supplied mineralized debris to the

748 anomaly on a glacis. For instance, an anomaly documented in the lowermost portion of a

749 relictual glacis i.e., close to or along a river active at the time of pedimentation, can be

750 sourced from the erosion of all the glacis that were connected downslope to that drain

751 upstream. For functional glacis, delimitation of the upslope area that contributed to a

752 sampling site would be straightforward because this area is constrained by the present-day 753 topography.

Maximal transportation distance on a glacis corresponds to the upslope distance

755 between the considered sampling site and the drainage divide at the end of the activity of

756 the glacis (i.e., before its abandonment and dissection). Reconstruction of the High glacis

757 landscape suggests that paleo-glacis widths have exceeded $20 \mathrm{~km}$ (Grimaud et al., 2015; Fig.

758 10), prompting to undertake landform-regolith mapping and paleolandscape reconstruction

759 on a larger scale than that of the immediate surrounding of the anomaly-bearing glacis relic.

760 South of the Sahelian zone (Fig. 2), dissection of the High glacis pediplain has generally

761 created narrower (1-10 km) Middle and Low glacis flanking subsequent valleys that are often

762 perpendicular to the earlier main river drain delimitating High glacis (Fig. 7). Potential

763 maximal transportation distances on those pediments are therefore reduced compared to

764 those of the High glacis and the transport direction at a high angle to that of the preexisting

765 glacis. The same reasoning as that exposed above applies to the tracking of the source of

766 transported regolith upslope on the Middle and Low glacis, bearing in mind that the cover of

767 these glacis can carry elements that may have previously been transported on an earlier

768 glacis. Potential divide migration from one glacis landscape stage to the next should also be

769 taken into account (e.g., Fig. 8). A given bedrock mineral concentration could indeed have

770 been subjected to pedimentation by successive glacis of contrasting slope directions and

771 therefore may not have always belonged to the same drainage sub-basin (Fig. 20). 
Stream sediment surveys going up river would still be valid in glacis environments,

773 providing that once propitious channel sections are selected, the upslope source tracing

774 protocol described above for glacis environment is applied. The geomorphological

775 exploration guides considered here do not only apply to resources transported as particles

776 such as gold, platinum or diamond, but also to ore deposits such as copper or manganese,

777 which can accumulate by downslope solute transfers through glacis cover (e.g., Sillitoe,

778 2005; Riquelme et al., 2018).

779

780

781

\section{3. Targeting concealed resource}

782 West African exploration challenge is to detect the resources they potentially mask. A way to

783 contribute to targeting such resources is to identify glacis units potentially masking

784 mineralized bedrock lithologies, structures or dikes that were first identified and mapped

785 independently from scattered outcrops or boreholes. By combining the geological map and

786 a landform-regolith map, one obtains by a GIS overlay operation the intersection between

787 polygons representing glacis ferricrete units, on the one hand, and polylines or polygones

788 representing mineralized faults, dykes or rock units, on the other hand. As an illustration of

789 such a GIS request, Figure 21 shows gold, copper and manganese indices over Southwestern

790 Burkina Faso as well as the High glacis ferricrete relics overlying (i.e., intersecting) bedrock

791 lithological units bearing those indices. This representation allows (i) targeting High glacis

792 ferricrete relics potentially masking deposits and (ii) adapting a sampling or drilling strategy

793 accordingly. Those targeted glacis ferricrete units should then be studied in details and

794 eventually be drilled across to attain the projected trace of the mineralized structure under

795 the glacis cover. Such a protocol would typically reveal lateral extensions of ore bodies and 
796 may be applied from a regional (10-100 km) (Fig. 21) to a prospect scale (0.1-1 km) if

798

799

800

801

802

803

804

805

806

807

808

809

810

811

812

813

814

815

816

817

818

819

820

\section{4. Other geomorphic exploration pitfalls and overlooked resources}

The pervasive occurrence and preservation of convexo-concave rolling pediplains south of the Sahelian zone and the degradation of glacis into concave residual hills under equatorial environments explain why glacis may have been overlooked, especially by workers who did not investigate landforms outside the Forest zone, contrary to Grandin (1976), who worked across an entire regional latitudinal corridor. Exploration geologists have indeed implicitly interpreted residual hills as "demi-oranges" (e.g., Freyssinet, 1993; Freyssinet et al., 2005) although they may result from pedimentation in the case of rolling pediplains or from the degradation of older glacis into convex hills. A consequence of such restrictive interpretation is that ferricretes / lateritic residua are considered as formed and preserved essentially in-situ, whereas they could host material transported prior to weathering/duricrusting. A residual hill can result from the dismantling of a wide glacis on which material has been transported over several kilometers if not tens of kilometers i.e., on a much larger scale than the size of the residual hill. However, detailed exploration geochemical investigations or models are restricted to the slope of a single residual hill (e.g., Zeegers and Lecomte, 1992; Freyssinet, 1993; Butt, 2016). In glacis landscapes such as those of West Africa, landform-regolith mapping and the establishment of a landscape chronology should therefore be undertaken on a larger scale $(1-20 \mathrm{~km})$ than that of the considered anomaly-bearing relief $(0,1-1 \mathrm{~km})$.

Given the alluvial nature of glacis overburdens, placers must be common on pediments. Detailed work by Thomas and Thorp $(1985)$ or Teuuw $(1987,2002)$ suggests that alluvial diamonds are hosted by paleo-glacis systems' residual hills. Recent unconsolidated 
821 glacis overburden is commonly mined for gold placers. Those artisanal mines are valuable

822 proxies of upslope bedrock mineralizations by using the geomorphological guides provided

823 above. Downslope parts of Low glacis and alluvial terraces host gold and diamond placers

824 (e.g., Hall et al., 1985; Teeuw et al., 1991; Ouangrawa et al., 1996). But older glacis ferricretes

825 should also bear numerous unsuspected alluvial placers. Although weathering of the High

826 glacis has contributed locally to elluvial gold concentrations, it is mostly the thick and

827 mature weathering profiles of the Bauxitic and Intermediate paleolandsurfaces that have a

828 high - and still largely overlooked - potential of hosting supergene ore concentrations others

829 that those that are known and actively mined for ( $\mathrm{Al}, \mathrm{Mn}$ and $\mathrm{Au}$ ).

830

\section{8. Pediments, pediplains and the topographic evolution of shields}

\section{8. 1. Implications for pedimentation in lateritic landscapes}

Thanks to the protective effect of the ferricretes and limited regional denudation,

834 there is a significant spatial and temporal variability in the glacis record from the scale of a

835 single pediment to that of the African sub region. As composite landform-regolith

836 associations, pediments erode, collect, transport, sort, transform and store regolith through

837 space and time. An overwhelming part the of the West African pediments are cut exclusively

838 in a thick ( $>20 \mathrm{~m}$ ) preexisting regolith mantle and a single pediment may be both cut through

839 preexisting regolith upslope and through bedrock downslope. The very common occurrence

840 of rolling pediplains also shows that pediments encompass the entire regional relief and

841 therefore cap interfluves. The West African case study therefore suggests that lateritic

842 pediments may not be appropriately distinguished by morphogenic classifications based on

843 (i) the shape or position of pediments in the lansdcape (Cook and Mason, 1973), (ii) the

844 relations between regolith and the bedrock as criteria of the pedimentation process

845 (Twidale, 1983), (iii) the nature of the material being cut (Dresch, 1957; Tricart, 1972; 
846 Oberlander, 1989) or (iv) the thickness of the transported overburden (Applegarth, 2004) (see

847 Dohrenwend and Parsons, 2009 for review). Likewise, a comprehensive definition of the

848 physical and chemical processes involved in pedimentation would be therefore, to our view,

849 vain. Pre-Neogene weathering was instrumental at preparing the thick regolith mantle made

850 available to stepwise pedimentation. But evaluation of the role of weathering during the

851 formation of glacis would not be straightforward given the imprint of the post

852 pedimentation weathering and duricrusting of the pediments. At best, an increasing

853 activation / influence of the pedogenetic processes is expected in pedimentation across the

854 latitudinal gradient towards the Equator (e.g., Millot, 1980, 1983; Rohdenburg, 1969, 1982).

855

\section{8. 2. Relations to epeirogeny}

857 Pediment systems carved the African surface while it was being submitted to long

858 wavelength $\left(10^{3} \mathrm{~km}\right)$ deformation that contributed to the growth of the basin-and-swell

859 topography of the continent after $40 \mathrm{Ma}$ (Burke and Gunnell, 2008; Chardon et al., 2016). The

860 most prominent element of that physiography in West Africa is the Hoggar swell; but more

861 subtle uplift is also suggested along the marginal upward that constituted the eastern

862 extension of the Guinean rise up to the Jos Plateau (Grimaud et al., 2014, 2018; Chardon et

863 al., 2016; Fig. 2). The stepping patterns of pediment systems may not be used as a proxy of

864 that deformation because glacis have a roughly spatially consistent and reduced $(<80 \mathrm{~m})$

865 elevation range above local base level, which itself varies with river networks from sea level

866 to above $1300 \mathrm{~m}$ for the highest regional topographic massifs excluding the Hoggar

867 (Grimaud et al., 2014; Fig. 2). In details, the stepping pattern of successive glacis has been

868 compartmentalized amongst sub drainage areas due to spatially variable incision of river

869 segments bounded by stationary knickzones, which were already part of the West African

870 landscape before settlement of the High glacis pediplain for most of them (Grimaud et al., 
871 2014). Furthermore, glacis systems did not level out regional rock escarpments, which were

872 already imprinted in the Paleogene Bauxitic and (mostly) Intermediate landscapes and

873 remained almost stationary since then (De Swardt, 1964; Grandin and Delvigne, 1969; Burke

874 and Gunnell, 2008; Grandin and Joly, 2008; Grimaud et al., 2014, 2015; Fig. 17). Glacis

875 systems therefore adapted their slopes to differentiated and uneven river levels and

876 contributed in this way to distributed landscape dissection and dismantling down to the

877 scale of lowermost-order drains a few kilometers long (e.g., Figs. 8, 9, 10). In other words,

878 outside the provinces of relict African and Intermediate landscapes (Fig. 17), virtually no $20 \mathrm{x}$

$87920 \mathrm{~km}$ area of the West African topography escaped settlement of new glacis during the main

880 pedimentation periods, with the exception of Low glacis pedimentation at lowermost

881 latitudes (Fig. 18).

882 Thorough documentation of stepwise Cenozoic dissection of the West African sub

883 region therefore precludes the stepping of successively younger pediplains bounded

884 upstream by escarpments, which would produce continental-scale staircase patterns of

885 pediplains from the crest of swells down to sea level or the base level of intracratonic basins.

886 Such a model is suggested by Burke and Gunnell (2008, their Figure 16A) on the crest and

887 slopes of the Guinean Rise (Fig. 2). Staircase pediplains models derive from that of King

$888(1948,1967)$ in which continent-wide and flat pediplains graded to sea level form by

889 escarpment/knickzone retreat far inland. For King, a pediplain is abandoned as a

890 consequence of uplift by the formation of a subsequent pediplain below a new retreating

891 escarpment, which will ultimately bound and protect the relic of the early pediplain in the

892 continental interior. King's paradigm is also explicit in the procedure that would allow

893 retrieving long-term continental uplift histories from the inversion of current river

894 longitudinal profiles (Paul et al., 2014). This procedure is indeed based on a quantitative

895 model that explicitly requires inlandward retreat of river knickzones in response to uplift and 
896 is therefore invalidated by the well-documented West African case study (Grimaud et al.,

897 2014). A staircase model of pediplains has also been proposed by Guillocheau et al. (2015,

898 2017) for the Congo basin and its surrounding swells and by Dauteuil et al. (2015) for

899 Namibia. The definition of a pediment system by these authors as a flat pediplain connected

900 upslope to pediments (pediment valleys) and higher up to rivers incising the older

901 upstanding landsurface across escarpments (e.g., Guillocheau et al., 2015) therefore

902 contrasts with that implied by the West African case study. The difference between the two

903 models is not only conceptual. Regional correlations of West African glacis systems are

904 based on well-preserved regolith-landform associations and geomorphic criteria, whereas

905 those of Central and Southwestern Africa have to rely mostly on topographic correlations

906 and escarpment identification in contexts of advanced degradation of the regolith-landform

907 associations or in absence of type-regolith-landform associations in arid Southwestern

908 Africa. The topographic approach would intrinsically favor a Kingian model and vice-versa.

909 The West African case study indicates that pediments achieved local planation and

910 formed from the development of the drainage network instead of by dominant range retreat.

911 The difficulty to relate the regional stepping patterns of pediment systems to an inferred

912 pattern of uplift over West Africa suggests that shield landscape dissection schemes would

913 primarily be driven by long-term climatic oscillations driving pedimentation / weathering

914 periods along low-abrasion capacity river networks (e.g., Tricart 1959; Beauvais and Chardon, 915 2013).

916

917 8. 3. Pediment landscape evolution processes and the sediment routing system

918 Surface process models suggest that non-orogenic continental surfaces such as that

919 of Africa develop non-steady state (transient) landscapes with a Davisian behavior of long-

920 term decreasing slope angle (Davis, 1899; Bishop, 2007). African landscapes saw their relief 
921 increasing throughout the Cenozoic and should then be considered as transient over the

922 very long term. But the punctuated pedimentation scheme they developed does not match

923 that of the Davisian cycle of erosion. The main specificity of the West African landscape

924 dissection patterns by pedimentation is a progressively reduced area submitted to abrasion

925 through time, leaving increasingly wider relict surfaces of limited or no denudation as a

926 result of landscape dissection (Fig. 10). The stepping patterns of pediment systems have no

927 clear dependency on sea level variations and/or epeirogeny and contribute to limited (3-9

$928 \mathrm{~m} / \mathrm{My}$ ) and distributed denudation. In contexts of enhanced uplift and correlatively higher

929 denudation such as the upper slope of the Hoggar swell (surface uplift and denudation > 30

930 m/My since ca. 35 Ma; Chardon et al., 2016; Grimaud et al., 2018), pediplains could not form

931 or be preserved on geological time scales.

932 Once duricrusted and/or abandoned as a result of dissection, pediments preserve

933 the underlying regolith from erosion. Regional-scale pediment systems (pediplains) form

934 and maintain over geological timescales in environments submitted to low river incision or

935 erosion rates $(<10 \mathrm{~m} / \mathrm{Ma})$ and limited epeirogenic uplift. Under that condition, the

936 maintenance of very slowly evolving pediment landscapes poses the chicken-and-egg issue

937 of knowing whether the low erosional efficiency of pedimentation dictates the limited

938 transport and incision capacity of the river network or vice-versa. In any case, pediments are

939 buffer landsurfaces between the regolith mantles they contribute to exhume and the rivers

940 they feed with reworked regolith (Grimaud et al., 2015). Pedimentation is transport-limited

941 given the large amount of (old) regolith still being stored in West African landscapes, which

942 generates subdued and nearly constant erosion fluxes over the long-term $<0.01$

$\left.943 \mathrm{~km}^{3} / \mathrm{km}^{2} / \mathrm{My}\right)$. Above a $10 \mathrm{~m} /$ My incision/erosion rate threshold, rupture of the

944 pedimentation regime is expected, paleo-landforms being erased. It is only above several

945 tens of meters per million years of long-term erosion that denudation would potentially 
946 become measurable by low-temperature thermochronology (Beauvais et al., 2016). The

947 regional preservation of pediments / pediplains indicative of very slow denudation should

948 then prevent retrieval of denudation scenarios from low-temperature thermochronology for

949 periods encompassing pediments timespan of formation and over periods following their

950 abandonment. Dated relict pediments should be used instead as strict constraints on the

951 late temperature-time exhumation path provided by low-temperature thermochronology.

952

953

\section{Conclusions}

954

Throughout its surface, Sub Saharan West Africa preserves three Neogene (24-3 Ma)

955 lateritic pediment systems as well as functional pediments along the southern fringe of the

956 Sahara. A review of the landform-regolith associations, landscape chronologies, ages and

957 stepping patterns of the pediments as well as their spatial distribution and active

958 degradation modes bears implications for the long-term landscape evolution processes of

959 shields and mineral exploration strategies in the tropical belt. Those implications may be

960 summarized as follows.

9611 - Pediments occupy an overwhelming surface of the sub region and contributed to

962 removal of a thick lateritic regolith mantle resulting from intense pre-Neogene weathering.

963 Each pediment system formed by the process of relief dissection and incorporated

964 landforms inherited from earlier landscapes. Depending on the nature of the geological

965 substrate, pediment paleolandscape stages comprised regions of multiconcave pediplains

966 and regions of multi-convexo-concave pediplains (called rolling pediplains).

9672 - A great spatial diversity exists in the pediments regolith associations owing to the nature

968 of the substrate pediments have leveled, the origin, transport dynamics and preservation of

969 the materials that have been transiting on their surface and the intensity of weathering and

970 duricrusting their have undergone. However, detrital ferricretes and loose clastic sediments 
971 constitute by far the most common type of pediment surface. Fe-duricrusting and ferricretes

972 constitute a necessary condition for glacis dissection and preservation of relictual

973 landscapes.

9743 - Lateritic pediment surfaces are not suitable for geochemical sampling aiming at

975 obtaining reliable information about the composition of the bedrock or an elemental

976 concentration anomaly. The two main reasons for this are (i) the transported nature of the

977 material exposed at the surface and (ii) the lost of the geochemical characteristics of the

978 bedrock through the weathering processes.

9794 - Landform-regolith mapping beyond the scale of modern interfluves followed by

980 reconstitution of past pediment landscape stages provides geomorphological exploration

981 guides for interpreting surface geochemical anomalies on pediments and tracing their

982 potential sources in case they have been "transported" on pediments. Mapping of landform-

983 regolith associations may also be used to target pediments masking suspected

984 mineralizations.

9855 - Past and present latitudinal climatic zonation of pedimentation and weathering at the

986 scale of the sub region suggests a gradient of pedimentation processes from an arid to a

987 perhumid end-member across the intertropical zone. They also explain why pediments may

988 have been overlooked in humid equatorial environments, with important implications for

989 mineral exploration.

9906 - Successive pediment systems have affected progressively reduced area over time,

991 preserving increasingly wider relictual landsurfaces. Climatic oscillations dictated

992 pedimentation-driven, local planation that adapted slopes to very large, spatially

993 differentiated, knickzone bearing river networks. The spatially consistent and limited $(<80$

$994 \mathrm{~m})$ stepping pattern of pediments is independent from elevation or distance to base level.

995 Hence, pediments and pediplains may not be used as gauges of uplift except near coastlines. 
996 Pediments form and are preserved regionally over geological timescales only for $<10 \mathrm{~m} / \mathrm{My}$

997 erosion regimes and are therefore indicators of very slow shield denudation.

9987 - Lateritic pediments have been overlooked in the tropical belt because lateritic

999 duricrusted landscapes refer exclusively to in-situ weathering of bedrock for most geologists

1000 and geochemists. Further investigations will hopefully help deciphering pediment landform-

1001 regolith associations for a better access to the geological substrate of tropical shields and its

1002 resources that may still be underestimated. Investigating pediments as markers of past

1003 morphogenesis is a powerful tool for understanding surface dynamics of shields and their

1004 sediment routing system, which contribute to a significant proportion of the Earth

1005 sedimentary budget and global biogeochemical cycles.

1006

\section{Acknowledgments}

1008 This work is published with the support of IRD (JEAI FasoLith). It has been mostly funded by

1009 the TopoAfrica project (ANR-08-BLAN-572 0247-02), the West African eXploration Initiative

1010 (WAXI) and the CNRS. Further support from TS2P (the Transform Source-to-Sink Project)

1011 funded by Total Exploration and Production is acknowledged. The paper benefited from the

1012 comments and suggestions of three anonymous reviewers. We acknowledge AMIRA

1013 International, the industry sponsors and the Geological Surveys / Departments of Mines in

1014 West Africa for their support of the WAXI project (P934A). 
1017 Anand, R., Lintern, M., Noble, R., Aspandiar, M., Macfarlane, C., Hough, R., Stewart, A.,

1018 Wakelin, S., Townley, B., Reid, N., 2014. Geochemical dispersion through transported cover in regolith-dominated terrains - toward an understanding of process. Soc. Econ. Geol. Spec. Publ. 18, 97-125.

Applegarth, M.T., 2004. Assessing the influence of mountain slope morphology on pediment form, South-Central Arizona. Phys. Geogr. 25, 225-236.

Aubréville, A., 1949. Climats, forêts et désertification de l'Afrique tropicale. Société d'Editions géographiques maritimes et coloniales, Paris.

Bamba, O., 1996. L'or disséminé dans les Albitites de Larafella (Burkina Faso), évolution dans les altérites et les cuirasses ferrugineuses : Métallogénie - Pétrologie - Géomorphologie. Ph D Thesis, Aix-Marseille III University, Marseille, 261p.

Bamba, O., 2009. Morphopédologie et anomalie géochimique. Can. J. Earth Sci. 46, 939-948.

Bamba, O., Parisot, J.-C., Grandin, G., Beauvais, A., 2002. Ferricrete genesis and supergene gold behaviour in Burkina Faso, West Africa. Geochem. Explor. Environ. Anal. 2, 3-13.

Baratoux, L., Metelka, V., Naba, S., Jessell, M.W., Gregoire, M., Ganne, J., 2011. Juvenile Paleoproterozoic crust evolution during the Eburnean orogeny (similar to 2.2-2.0 Ga), western Burkina Faso. Precambrian Res. 191, 18-45.

Beaudet, G., Coque, R., 1994. Reliefs et modelés des régions tropicales humides : mythes, 
1039 Beauvais, A., Ritz, M., Parisot, J.C., Dukhan, M., Bantsimba, C., 1999. Analysis of poorly

1040 stratified lateritic terrains overlying a granitic bedrock in West Africa, using 2-D electrical

1041 resistivity tomography. Earth Planet. Sci. Lett. 173, 413-424.

1042 Beauvais, A., Ritz, M., Parisot, J.C., Bantsimba, C., 2003. Testing etching hypothesis for the 1043 shaping of granite dome structures beneath lateritic weathering landsurfaces using ERT 1044 method. Earth Surf. Process. Landf. 28, 1491-1491.

1045 Beauvais, A., Ritz, M., Parisot, J.C., Bantsimba, C., Dukhan, M., 2004. Combined ERT and GPR methods for investigating two-stepped lateritic weathering systems. Geoderma 119, 121132.

1048 Beauvais, A., Chardon, D., 2013. Modes, tempo, and spatial variability of Cenozoic cratonic 1049 denudation: The West African example. Geochem. Geophys. Geosyst. 14, 1590-1608.

1050 Beauvais, A., Ruffet, G., Henocque, O., Colin, F., 2008. Chemical and physical erosion rhythms 1051 of the West African Cenozoic morphogenesis: The ${ }^{39} \mathrm{Ar}-{ }^{40} \mathrm{Ar}$ dating of supergene K-Mn 1052 oxides. J. Geophys. Res.-Earth Surf. 113, F4007.

1053 Beauvais, A., Bonnet, N.J., Chardon, D., Arnaud, N., Jayananda, M., 2016. Very long-term 1054 stability of passive margin escarpment constrained by Ar-40/Ar-39 dating of K-Mn oxides. 1055 Geology 44, 299-302.

1056 Bishop, P., 2007. Long-term landscape evolution: linking tectonics and surface processes. 1057 Earth Surf. Process. Land. 32, 329-365.

1058 Bitom, D., Volkoff, B., Beauvais, A., Seyler, F., Ndjigui, P.D., 2004. Rôle des héritages

1059 latéritiques et du niveau des nappes dans l'évolution des modelés et des sols en zone 1060 intertropicale forestière humide. C.R. Géoscience 336, 1161-1170.

1061 Boeglin, J.L., Mazaltarim, D., 1989. Géochimie, degrés d'évolution et lithodépendance des 1062 cuirasses ferrugineuses de la région de Gaoua au Burkina Faso. Sci. Géol. Bull. 42, 27-44. 
1063 Bolster, S.J.S., 1999. Regolith mapping: Is it really necessary? Aus. Inst. Geoscent. Bull. 30, $1064 \quad 125-135$.

1065 Bonvallot, J., Boulangé, B., 1970. Note sur le relief et son évolution dans la région de Bongouanou (Côte d'Ivoire). Cah. ORSTOM Sér. Géol. 2, 171-183.

1067 Boulangé, B., 1984. Les formations bauxitiques latéritiques de Côte d'Ivoire. Trav. Doc.

1068 ORSTOM 175, 1-342.

1069 Boulangé, B., 1986. Relation between lateritic bauxitization and evolution of landscape. Trav. 1070 Int. Com. Stud. Bauxite, Alumina \& Aliminum (ISCOBA) 16-17, 27-44.

1071 Boulangé, B., Millot, G., 1988. La distribution des bauxites sur le craton ouest-africain. Sci. 1072 Géol. Bull. 41, 113-123.

1073 Boulangé, B., Sigolo, J.B., Delvigne, J., 1973. Descriptions morphoscopiques, géochimiques 1074 et minéralogiques des faciès cuirassés des principaux niveaux géomorphologiques de 1075 Côte d'Ivoire. Cah. ORSTOM Sér. Géol. 5, 59-81.

1076 Boulet, R., 1970. La géomorphologie et les principaux types de sols en Haute-Volta 1077 septentrionale. Cah. ORSTOM Sér. Pédol. 8, 245-271.

1078 Bowden, D.J., 1987. On the composition and fabric of the footslop laterites (duricrusts) of 1079 the Sierra Leone, West Africa, and their geomorphological significance. Z. Geomor. N.F. 64, $1080 \quad 39-53$.

1081 Bowden, D.J., 1997. The geochemistry and development of lateritized footslope benches: 1082 The Kasewe Hills, Sierra Leone. Spec. Publ. Geol. Soc. 120, 295-305.

1083 Bowell, R.J., Afreh, E.O., Laffoley, N.d.A., Hanssen, E., Abe, S., Yao, R.K., Pohl, D., 1996. 1084 Geochemical exploration for gold in tropical soils - four contrasting case studies from 1085 West Africa. Trans. Inst. Min. Metall. 105, B12-B33.

1086 Brammer, H., 1955. Visit to Haute Volta, $30^{\text {th }}$ January- $3^{\text {rd }}$ March 1955. Gold Coast Dept. Soil 1087 Land-Use Surv. Techn. Rep. 9, 1-48. 
1088 Brammer, H., 1956. A note on former pediment remnants in Haute Volta. Geogr. J. 122, 526-

1089527.

1090 Brown, D.J., Helmke, P.H., Clayton, M.K., 2003. Robust geochemical indices for redox and 1091 weathering on a granitic laterite landscape in Central Uganda. Geochim. Cosmochim. $1092 \quad$ Acta 67, 2711-2723.

1093 Brückner, W.D., 1955. The mantle rock (laterite) of the Gold Coast and its origin. Geol. $1094 \quad$ Rundsch. 43, 307-327.

1095 Büdel, J., 1982. Climatic geomorphology. Princeton University Press, Princeton.

1096 Bull, W.B., 1977. The alluvial-fan environment. Progr. Phys. Geogr. 1, 222-270.

1097 Burke, K., Durotoye, B., 1971. Geomorphology and superficial deposits related to Late 1098 Quaternary climatic variation in South-Western Nigeria. Z. Geomor. N.F. 15, 430-444.

1099 Burke, K., Gunnell, Y., 2008. The African erosion surface: A continental scale synthesis of 1100 geomorphology, tectonics, and environmental change over the past 180 million years. 1101 Geol. Soc. Am. Mem. 201, 1-66.

1102 Butt, C.R.M., 2016. The development of regolith exploration geochemistry in the tropics and 1103 sub-tropics. Ore Geol. Rev. 73, 380-393.

1104 Butt, C.R.M., Bristow, A.P.J., 2013. Relief inversion in the geomorphological evolution of sub1105 Saharan West Africa. Geomorphology 185, 16-26.

1106 Butt, C.R.M., Lintern, M.J., Anand, R.R., 2000. Evolution of regoliths and landscapes in deeply 1107 weathered terrain - implications for geochemical exploration. Ore Geol. Rev. 16, 167-183.

1108 Butt, C.R.M., Zeegers, H., 1989. Classification of geochemical exploration models for 1109 tropically weathered terrains. J. Geochem. Explor. 32, 65-74.

1110 Castaing, C., Le Metour, J., Billa, M., Donzeau, M., Chevremont, P., Egal, E., Zida, B., 1111 Ouedraogo, I., Koté, S., Kaboré, B.E., Ouedraogo, C., Thieblemont, D., Guerrot, C., 
1112 Cocherie, A., Tegyey, M., Itard, Y., Milesi, J.P., 2003. Carte géologique et minière du

1113 Burkina Faso à 1/1 000 000. BRGM/BUMIGEB.

1114 Chardon, D., Chevillotte, V., Beauvais, A., Grandin, G., Boulangé, B., 2006. Planation, bauxites 1115 and epeirogeny: One or two paleosurfaces on the West African margin? Geomorphology $1116 \quad 82,273-282$.

1117 Chardon, D., Grimaud, J.L., Rouby, D., Beauvais, A., Christophoul, F., 2016. Stabilization of 1118 large drainage basins over geological time scales: Cenozoic West Africa, hot spot swell 1119 growth, and the Niger River. Geochem. Geophys. Geosyst. 17, 1164-1181.

1120 Colin, F., Vieillard, P., 1991. Behavior of gold in the lateritic equatorial environment -

1121 Weathering and surface dispersion of residual gold particles at Dondo Mobi, Gabon. Appl. 1122 Geochem. 6, 279-290.

1123 Colin, F., Beauvais, A., Ruffet, G., Henocque, O., 2005. First Ar-40/Ar-39 geochronology of 1124 lateritic manganiferous pisolites: Implications for the Palaeogene history of a West 1125 African landscape. Earth Planet. Sci. Lett. 238, 172-188.

1126 Cook, R.U., Mason, P.F., 1973. Desert Knolls Pediment and associated landforms in the 1127 Mojave Desert, California. Rev. Géomorph. Dyn. 22, 49-60.

1128 Dauteuil, O., Bessin, P., Guillocheau, F., 2015. Topographic growth around the Orange River 1129 valley, southern Africa: A Cenozoic record of crustal deformation and climatic change. 1130 Geomorphology 233, 5-19.

1131 Daveau, S., Lamotte, M., Rougerie, G., 1962. Cuirasses et chaines birrimiennes en Haute-Volta. 1132 Ann. Géogr. Franç. 387, 260-282.

1133 Davis, W. M., 1899. The geographical cycle. Geogr. J. 14, 481-504.

1134 De Swardt, A.M.J., 1964. Lateritisation and landscape development in parts of Equatorial 1135 Africa. Z. Geomor. N.F. 8, 313-333. 
Dohrenwend, J.C., Parsons, A.J., 2009. Pediments in arid environments, in: Parsons, A.,

1137 Abrahams, A. (Eds.), Geomorphology of desert environments, 2 ed. Springer Netherlands, $1138 \quad$ The Netherlands, pp. 377-411.

1139 Dresch, J., 1952a. Dépôts de couverture et relief en Afrique occidentale française. Proc. XVII th $1140 \quad$ Int. Geogr. Congr., Washington, 323-326.

1141 Dresch, J., 1952b. Dépôts superficiels et relief du sol au Dahomey septentrional. C. R. Acad. 1142 Sci. Paris 234, 1566-1568.

1143 Dresch, J., 1957. Pédiments et glacis d'érosion, pédiplaines et inselbergs. Inf. Géogr. 21, 183$1144 \quad 196$.

1145 Eschenbrenner, V., Grandin, G., 1970. La séquence de cuirasses et ses différentiations entre 1146 Agnibiléfrou et Diébougou (Haute-Volta). Cah. ORSTOM Sér. Géol. 2, 205-246.

1147 Fölster, H., 1964. Morphogenese der Südsudanesischen Pediplane. Z. Geomor. N. F. 8, 393$1148 \quad 423$.

1149 Fölster, H., 1969a. Late Quaternary erosion in SW-Nigeria. Bull. Ass. Sén. Et. Quat. Ouest Afr. $1150 \quad 21,29-35$.

1151 Fölster, H., 1969b. Slope development in SW-Nigeria during late Peistocene and Holocene. 1152 Göttinger Bodenkdl. Ber. 10, 3-56.

1153 Fölster, H., Moshrefi, N., Ojenuga, A.G., 1971. Ferralitic pedogenesis on metamorphic rocks, $1154 \quad$ SW-Nigeria. Pédologie 21, 95-124.

1155 Freyssinet, P., 1993. Gold dispersion related to ferricrete pedogenesis in South Mali: 1156 application to geochemical exploration. Chron. Rech. Min. 510, 25-40.

1157 Freyssinet, P., Butt, C.R.M., Morris, R.C., Piantone, P., 2005. Ore-forming processes related to 1158 lateritic weathering. Econ. Geol. 100 ${ }^{\text {th }}$ Anniversary volume, 681-722.

1159 Gavaud, M., 1977. Les grands traits de la pédogenèse au Niger méridional. Trav. Doc.

$1160 \quad$ ORSTOM 76, 1-102. 
1161 Goldfarb, R.J., André-Mayer, A.S., Jowitt, S.M., Mudd, G.M., 2017. West Africa: The World's

1162 premier Paleoproterozoic gold province. Econ. Geol. 112, 123-143.

1163 Grandin, G., 1976. Aplanissements cuirassés et enrichissement des gisements de manganèse 1164 dans quelques régions d'Afrique de l'Ouest. Mém. ORSTOM 82, 1-276.

1165 Grandin, G., 2008. Les cuirasses latéritiques - aluminisation et ferruginisation, in: Dewolf, Y., 1166 Bourrié, G. (Eds.), Les formations surperficielles. Genèse - typologie - classification -

1167 paysages et environnements - ressources et risques. Ellispes, Paris, pp. 362-372.

1168 Grandin, G., Delvigne, J., 1969. Traits généraux de l'évolution du réseau hydrographique 1169 dans la région du confluent Bandama - N'Zi (Côte d'Ivoire). Bull. Ass. Sén. Et. Quat. Ouest $1170 \quad$ Afr. 23, 7-14.

1171 Grandin, G., Hayward, D.F., 1975. Aplanissements cuirassés de la péninsule de Freetown 1172 (Sierra Leone). Cah. ORSTOM Sér. Géol. 7, 11-16.

1173 Grandin, G., Joly, F., 2008. Glacis - Genèse, dynamique et formations corrélatives, in: Dewolf, 1174 Y., Bourrié, G. (Eds.), Les formations surperficielles. Genèse - typologie - classification 1175 paysages et environnements - ressources et risques. Ellipses, Paris, pp. 201-216.

1176 Grimaud, J.L., Chardon, D., Beauvais, A., 2014. Very long-term incision dynamics of big rivers. $1177 \quad$ Earth Planet. Sci. Lett. 405, 74-84.

1178 Grimaud, J.L., Chardon, D., Metelka, V., Beauvais, A., Bamba, O., 2015. Neogene cratonic 1179 erosion fluxes and landform evolution processes from regional regolith mapping (Burkina $1180 \quad$ Faso, West Africa). Geomorphology 241, 315-330.

1181 Grimaud, J.L., Rouby, D., Chardon, D., Beauvais, A., 2018. Cenozoic sediment budget of West $1182 \quad$ Africa and the Niger delta. Basin Res., doi:10.1111/bre.12248.

1183 Guillocheau, F., Chelalou, R., Linol, B., Dauteuil, O., Robin, C., Mvondo, F., Callec, Y., Colin, J.1184 P., 2015. Cenozoic landscape evolution in and around the Congo Basin: Contraints from 

sediments and planation surfaces, in: De Wit, M.J. et al. (Eds.), Geology and resource

1186 potential of the Congo Basin. Springer-Verlag, Berlin Heidelberg, pp. 271-313.

1187 Guillocheau, F., Simon, B., Baby, G., Bessin, P., Robin, C., Dauteuil, O., 2017. Planation surfaces as a record of mantle dynamics: the case example of Africa. Gondwana Res., doi:

1190 Gunnell, Y., 2003. Radiometric ages of laterites and constraints on long-term denudation 1191 rates in West Africa. Geology 31, 131-134.

1192

Hall, A.M., Thomas, M.F., Thorp, M.B., 1985. Late Quaternary alluvial placer development in

1195 Hilton, T.E., 1963. The geomorphology of North-Eastern Ghana. Z. Geomor. N.F. 7, 308-325.

1196 Holmes, C.D., 1955. Geomorphic development in humid and arid regions: a synthesis. Am. J. 1197 Sci. 253, 377-390.

1198 King, L.C., 1948. On the Age of the African land-surfaces. Q. J. Geol. Soc. Lond. 104, 439-459. 1199 King, L.C., 1967. The morphology of the Earth, second ed. Oliver and Boyd, Edinburgh.

1200 Lamotte, M., Rougerie, G., 1953. Les cuirasses ferrugineuses allochtones. Signification 1201 paléoclimatique et rapports avec la végétation. IV Réun. African. de l'Ouest, Abidjan, 89120290

1203 Lamotte, M., Rougerie, G., 1962. Les apports allochtones dans la formation des cuirasses 1204 ferrugineuses. Rev. Géomor. Dyn. 13, 145-160.

1205 Le Cocq, A., 1986. Carte pédologique et carte des capacités agronomiques des sols à 1/100 1206 000, Région de Bassar (Togo). ORSTOM, Notice explicative 102, 1-103.

1207 Lecomte, P., 1988. Stone line profiles - Importance in geochemical exploration. J. Geochem. $1208 \quad$ Explor. 30, 35-61. 
1209 Lecomte, P., Zeegers, H., 1992. Humid tropical terrains (rainforests), in: Butt, C.R.M., Zeegers,

1210 H. (Eds.), Regolith exploration geochemistry in tropical and subtropical terrains. Elsevier, $1211 \quad$ Amsterdam, pp. 241-294.

1212 Leprun, J.C., 1979. Les cuirasses ferrugineuses des pays cristallins de l'Afrique occidentale 1213 sèche - génèse, transformation, dégradation. Sci. Géol. Mém. 58, 1-224.

1214 Mabbutt, J.A., 1966. Mantle-controlled planation of pediments. Am. J. Sci. 264, 78-91.

1215 Maignien, R., 1958. Le cuirassement des sols en Guinée, Afrique Occidentale. Mém. Serv.

1216 Carte Géol. Alsace Lorraine 16, 1-239.

1217 Maignien, R., 1966. Compte rendu de recherches sur les latérites. UNESCO, Paris.

1218 Markwitz, V., Hein, K.A.A., Jessell, M.W., Miller, J., 2016. Metallogenic portfolio of the West 1219 African craton. Ore. Geol. Rev. 78, 558-563.

1220 McFarlane, M.J., 1976. Laterite and landscape. Academic Press, London.

1221 Mensching, H., 1966. Flächenbildung in der Sudan-und Sahel-Zone (Ober-Volta und Niger). Z. 1222 Geomor. N.F. 10, 1-29.

1223 Metelka, V., Baratoux, L., Naba, S., Jessell, M.W., 2011. A geophysically constrained litho1224 structural analysis of the Eburnean greenstone belts and associated granitoid domains, 1225 Burkina Faso, West Africa. Precambrian Res. 190, 48-69.

1226 Metelka, V., Baratoux, L., Jessell, M.W., Barth, A., Jezek, J., Naba, S., 2018. Automated 1227 regolith landform mapping using airborne geophysics and remote sensing data, Burkina 1228 Faso, West Africa. Remote Sens. Environ. 204, 964-978.

1229 Meyer, B., 1992. A detailed soil differentiation of slopes with slight inclination in the $1230 \quad$ Niamtougou plain in North-Togo. Z. Geomor. N.F. 91, 124-134.

1231 Michel, P., 1959. L'évolution géomorphologique des bassins du Sénégal et de la Haute1232 Gambie, ses rapports avec la prospection minière. Rev. Géomorph. Dyn. 10, 117-143. 
1233 Michel, P., 1969. Les grandes étapes de la morphogenèse dans les bassins des fleuves

1234 Sénégal et Gambie pendant le Quaternaire. Bull. IFAN 31, 293-324.

1235 Michel, P., 1973. Les bassins des fleuves Sénégal et Gambie, étude géomorphologique. Mém.

\section{ORSTOM 63, 1-752.}

1237 Michel, P., 1974. Les glacis cuirassés d'Afrique occidentale et centrale. Géomorphologie des 1238 glacis : Colloques scientifiques de l'Université de Tours, Tours, France, pp. 70-80.

1239 Milesi, J.P., Ledru, P., Feybesse, J.L., Dommanget, A., Marcoux, E., 1992. Early Proterozoic

1240 Ore-Deposits and Tectonics of the Birimian Orogenic Belt, West Africa. Precambrian Res.

$124158,305-344$.

1242 Millot, G., 1980. Les grands aplanissements des socles continentaux dans les pays

1243 subtropicaux, tropicaux et désertiques. Mém. H. Sér. Soc. Géol. France 10, 295-305.

1244 Millot, G., 1970. The geology of clays. Springer-Verlag, Berlin.

1245 Millot, G., 1983. Planation of continents by intertropical weathering and pedogenetic

1246 processes. II ${ }^{\text {nd }}$ International Seminar on lateritisation processes, Sao Paulo, Brazil, July 4-

$1247 \quad 121982,53-63$.

1248 Nahon, D.B., Boulangé, B., Colin, F., 1992. Metallogeny of weathering : an introduction. in:

1249 Martini, I.P., Chesworth, W. (Eds.), Weathering, soils and paleosols. Elsevier, Amsterdam, $1250 \quad$ pp 445-467.

1251 Nahon, D., Millot, G. , Paquet, H., Ruellan, A., Tardy, Y., 1977. VII. Digestion et effacement des 1252 cuirasses ferrugineuses par les encroûtements calcaires en pays aride, Sahara et 1253 Mauritanie. Sci. Géol., Bull. 30, 289-296.

1254 Oberlander, T.M., 1989. Slope and pediment systems, in: Thomas, D.S.G. (Ed.), Arid zone 1255 geomorphology. Belhaven, London, pp. 56-84.

1256 Oberlander, T.M., 1997. Slope and pediment systems, in: Thomas, D.S.G. (Ed.), Arid zone 1257 geomorphology. Wiley, Chichester, pp. 135-163. 
1258 Ollier, C.D., Galloway, R.W., 1990. The Laterite Profile, Ferricrete and Unconformity. Catena

1260 Ollier, C.D., Pain, C.F., 1996. Regolith stratigraphy: principles and problems. AGSO J. Aust.

1261 Geol. Geophys. 16, 197-202.

1262 Ouangrawa, M., Grandin, G., Parisot, J.-C., Baras, E., 1996. Dispersion mécanique de l'or dans 1263 les matériaux de surface : exemple du site aurifère de Piéla (Burkina-Faso). Pangea 25, 25$1264 \quad 40$.

1265 Parisot, J.-C., Ventose, V., Grandin, G., Bourges, F., Debat, P., Tollon, F., Millot, L., 1995. Dynamique de l'or et d'autres minéraux lourds dans un profil d'altération cuirassé du Burkina Faso (Afrique de l'Ouest). Intérêt pour l'interprétation de la mise en place des matériaux constituant les cuirasses de haut-glacis. C.R. Acad Sci. Paris 301, 295-302.

Paul, J.D., Roberts, G.G., White, N., 2014. The African landscape through space and time. Tectonics 33, 898-935.

Payne, A.L., 1969. Exploration on pediments. Econ. Geol. 64, 117.

Pease, R.C., 2015. Understanding Pediments for Mineral Exploration, in: Pennell, W.M., Garside, L.J. (Eds.), Geological Society of Nevada's Symposium, Sparks, May 14-23, 2015. New Concepts and Discoveries, pp. 1365-1372.

Pélissier, P., Rougerie, G., 1953. Problèmes morphologiques dans le bassin de Siguiri (Haut Niger). Bull. I.F.A.N. 15, 1-47.

1281 Riquelme, R., Tapia, M., Campos, E., Mpodozis , C., Carretier, S., González, R., Muñoz, S., 1282 Fernandez-Mort, A., Sanchez, C., Marquardt, C., 2017. Supergene and exotic Cu 

mineralization occurs during periods of landscape stability in the Centinela Mining

1284 District, Atacama Desert. Basin. Res., doi: 10.1111/bre.12258.

Rohdenburg, H., 1969. Hangpedimentation and klimawechsel als wichtigste faktoren der 133.

1289 Rohdenburg, H., 1982. Geomorphologisch-bodenstratigraphischer Vergleich zwischen dem flächen- und stufenbildung in den wechselfeuchten tropen an beispielen aus Westafrica, besonders aus dem schichtstufenland Südost-Nigerias. Göttinger Bodenkdl. Ber. 10, 57-

Rohdenburg, H., 1982. Geomorphologisch-bodenstratigraphischer Vergleich zwischen dem Nordostbrasilianischen Trockengebiet und immerfeucht-tropischen Gebieten Sfidbrasiliens mit Ausf'tihrungen zum Problemkreis der Pediplain-PedimentTerrassentreppen. Catena Suppl. 2, 74-122.

Roquin, C., Freyssinet, P., Zeegers, H., Tardy, Y., 1990. Element distribution patterns in laterites of southern Mali. Consequence for geochemical prospecting and mineral exploration. Appl. Geochem. 5, 303-315.

Ruhe, R.V., 1956. Landscape evolution in the High Ituri, Belgian Congo. Publ. Inst. Nat. Et. Agron. Congo Belge 66, 1-108.

Sanfo, A., Colin, F., Delaune, M., Boulangé, B., Parisot, J.-C., Bradley, R., Bratt, J., 1993. Gold: a useful tracer in sub-Sahelian laterites. Chem. Geol. 107, 323-326.

Sanfo, Z., Grandin, G., Parisot, J.-C., Pale, F., 1992. Aplanissements latéritisés anciens, glacis 
1308 Summerfield, M.A., 1985. Plate tectonics and landscape development on the African

1309 continent, in: Morisawa, M., Hack, J.T. (Eds.), Tectonic geomorphology. Allen \& Unwin, $1310 \quad$ Boston, pp. 27-51.

1311 Summerfield, M.A., 1991. Global geomorphology. Longman Scientific \& Technical, Harlow.

1312 Summerfield, M.A., 1996. Tectonics, geology, and long-term landscape development, in:

1313 Adams, W.M., Goudie, A.S., Orme, A.R. (Eds.), Physical geography of Africa. Oxford

$1314 \quad$ University Press, Oxford, pp. 1-17.

1315 Tardy, Y., 1997. Petrology of laterites and tropical soils. Balkema, Rotterdam.

1316 Tardy, Y., Mazaltarim, D., Boeglin, J.L., Roquin, C., Pion, J.C., Paquet, H., Millot, G., 1988.

1317 Lithodépendance et homogénéisation de la composition minéralogique et chimique des

$1318 \quad$ cuirasses ferrugineuses latéritiques. C. R. Acad. Sci. Paris 307, 1765-1772.

1319 Tardy, Y., Roquin, C., 1992. Geochemistry and evolution of lateritic landscapes, in: Martini, 1320 I.P., Chesworth, W. (Eds.), Weathering, soils and paleosols. Elsevier, Amsterdam, pp. 4071321444.

1322 Tardy, Y., Roquin, C., 1998. Dérive des continents, paléoclimats et altérations tropicales. 1323 Editions BRGM, Orléans.

1324 Teeuw, R.M., 1987. Variations in the composition of gravel layers across the landscape.

1325 Examples from Sierra Leone. Geo-Eco. Trop. 11, 151-169.

1326 Teeuw, R.M., 2002. Regolith and diamond deposits around Tortiya, Ivory Coast, West Africa.

$1327 \quad$ Catena 49, 111-127.

1328 Teeuw, R.M., Thomas, M.F., Thorp, M.B., 1991. Geomorphology applied to exploration for 1329 tropical placer deposits, Alluvial mining. Elsevier Applied Science, London, New York, pp. $1330 \quad 458-480$.

1331 Thomas, M.F., 1978. The study of inselbergs. Z. Geomor. N. F. 31, 1-41. 
Thomas, M.F., 1980. Timescale of landform development on tropical shields - A study from Geomorphology. Wiley, Chichester, pp. 333-354.

\section{5}

Thomas, M.F., 1989. The role of etch processes in landform development. 2. Etching and the

\section{7} formation of relief. Z. Geomorph. N. F. 33, 257-274.

Thomas, M.F., 1994. Geomorphology in the tropics: A study of weathering and denudation in 1343 Thomas, M.F., Thorp, M.B., Teeuw, R.M., 1985. Paleogeomorphology and the occurrence of diamondiferous placer deposits in Koidu, Sierra Leone. J. Geol. Soc. 142, 789-802.

1351 Occidentale. Fifth Congr. INQUA, Madrid-Barcelona, 1957, 187-188.

1352 Tricart, J., 1959. Observations sur le façonnement des rapides des rivières intertropicales. 1353 Bull. Sect. Géogr. Com. Trav. Hist. Sci. LXXI, 289-313.

1354 Twidale, C.R., 1983. Pediments, peneplains, and ultiplains. Rev. Géomor. Dyn. 32, 1-35.

1355 Twidale, C.R., 1991. A Model of Landscape Evolution Involving Increased and Increasing 1356 Relief Amplitude. Z Geomor. N.F. 35, 85-109. 
1357 Twidale, C.R., Bourne, J.A., 2013. Do pediplains exist? Suggested criteria and examples. Z.

$1358 \quad$ Geomor. 57, 411-428.

1359 Valeton, I., 1991. Bauxites and Associated Terrestrial Sediments in Nigeria and Their Position 1360 in the Bauxite Belts of Africa. J. Afr. Earth Sci. 12, 297-310.

1361 Valeton, I., 1994. Element Concentration and Formation of Ore-Deposits by Weathering. 1362 Catena 21, 99-129.

1363 Vasconcelos, P.M., Brimhall, G.H., Becker, T.A., Renne, P.R., 1994. Ar-40/Ar-39 Analysis of 1364 Supergene Jarosite and Alunite - Implications to the Paleoweathering History of the Western USA and West-Africa. Geochim. Cosmochim. Acta 58, 401-420.

Vogt, J., 1959a. Aspects de l'évolution morphologique récente de l'ouest africain. Ann. Géogr. 1367 Franç. 367, 193-206.

1368 Vogt, J., 1959b. Observations nouvelles sur les alluvions inactuelles de Côte d'Ivoire et de 1369 Haute-Guinée, 84 ème Congr. Soc. Sav., Dijon, pp. 205-210.

1370 Ye, J., Chardon, D., Rouby, D., Guillocheau, F., Dall'asta, M., Ferry, J.N., Broucke, O., 2017.

1371 Paleogeographic and structural evolution of northwestern Africa and its Atlantic margins 1372 since the early Mesozoic. Geosphere 13, 1254-1284.

1373 Zeegers, H., Lecomte, P., 1992. Seasonnally humid tropical terrains (savannas), in: Butt, 1374 C.R.M., Zeegers, H. (Eds.), Regolith exploration geochemistry in tropical and subtropical 1375 terrains. Elsevier, Amsterdam, pp. 203-240.

1376 Zeegers, H., Leprun, J.C., 1979. Evolution des concepts en altérologie tropicale et 1377 conséquences potentielles pour la prospection géochimique en Afrique occidentale 1378 soudano-sahélienne. Bull. Bur. Rech. Géol. Min. 2-3, 229-239.

1379 


\section{Figure captions}

1381

Figure 1. Definition of the main elements of a lateritic weathering profile.

1383

1384 Figure 2. Topography, drainage, climatic zonation and political borders of Sub-Saharan

1385 West Africa. Climatic zones are adapted from Aubréville (1949). Savannas typically

1386 encompass the Guinean and Soudanian zones. For convenience, the Saharan, Sahelian and Soudanian zones are grouped in the present work as "dry regions". Al: Algeria; Be: Benin; BF:

Burkina Faso; C: Cameroon; G: Gambia; GB: Guinea Bissau; Gu: Guinea; IC: Ivory Coast; L:

Liberia; Ma: Mali; Mau: Mauritania; Mo: Morocco; Na: Nigeria; Ni: Niger; Se: Senegal; SL: Sierra

1390 Leone; T: Togo.

1391

Figure 3. Gold dispersion model through the regolith for ferricrete-capped West African landscapes (adapted from Freyssinet et al., 2005). The model is mostly based on the examples of the Syama mine (e.g., Fig. 2) and Banankoro prospect (Mali).

1395

1396

Figure 4. Synthetic representation (a) and Ar-Ar chronology (b) of the West African landformregolith sequence (modified after Beauvais and Chardon, 2013 and Grimaud et al., 2015). ArAr dates (solid circles) are from Beauvais et al. (2008) for cryptomelane samples from

1399 Tambao locality (Fig. 2). Ar-Ar dates from Syama (Southern Mali) are from Vasconcelos et al. 1400 (1994) (Fig. 2). Colored vertical stripes correspond to the weathering periods of each 1401 generation of landform-regolith association as deduced from Ar-Ar dating in Tambao.

1403 Figure 5. Remnants of the West African morphoclimatic sequence as exposed in the Goren 1404 greenstone belt near Kaya, Central Burkina Faso. Above: east-looking GoogleEarth view; 
1405 below: interpretation based on field survey and photointerpretation (vertical exaggeration:

1406 x3). Areas in white are steep post-High glacis incision slopes exposing saprolite. Position of 1407 the $501 \mathrm{~m}$ height spot is $13.040825^{\circ} \mathrm{N} / 1.211588^{\circ} \mathrm{E}$.

1408

1409 Figure 6. Sketch cross-sections of the two main glacis landscapes in West Africa. (a)

1410 Piedmont of a bauxite-capped mesa in greenstone belt terrain (inspired from field surveys in

1411 the Kongoussi area, Northern Burkina Faso). Dashed lines represent the maximum original

1412 extent of each glacis surfaces. (b) Rolling pediplain of the Middle glacis over granitoid or

1413 sandstone terrains. Bedrock is shown in grey and saprolite in yellow. Note the different

1414 scales in (a) and (b).

1415

1416 Figure 7. Three successive glacis landscape stages of West African granite-greenstone

1417 terrains (modified after Eschenbrenner and Grandin, 1970). (a) High glacis stage. (b) Early

1418 settlement of the Middle glacis (yellow). (c) Installation of the Low glacis (light blue). The

1419 model is based on regional field surveys in Northern Ivory Coast and Southwestern Burkina

1420 Faso across the Guinean and Soudanian zones (Fig. 2).

1421

1422 Figure 8. Dissection patterns of West African glacis systems (modified after Grandin and Joly, 1423 2008). (a) Piedmont configuration of downslope-decreasing incision through time. (b)

1424 Piedmont configuration of downslope-increasing incision through time. Patterns (b) are 1425 favored along main river segments of enhanced/accelerated down cutting (i.e., base-level 1426 lowering), as opposed to patterns in (a) that are produced along main river segments of 1427 mitigated/reduced down cutting (see Grimaud et al., 2014). (c)-(e) dissection scenarios of a 1428 rolling pediplain. A High glacis rolling pediplain (c) may be degraded in two main types of 1429 landscapes depending on where dissection focuses. Landscape (d) results if erosion 
1430 predominates along the main river drains of the initial rolling plain. Landscape (e) results if

1431 erosion predominates in crestal regions of the initial rolling plain (black arrows point to the main river drain i.e., the local base level). In (d), the main slope portions of former glacis are

1433 preferentially preserved. In (e), mostly valley bottoms of the former rolling pediplain are

1434 preserved. In this case, the relief inversion concept strictly applies, as lower parts of the

1435 ancient landscape become the highest parts of the new landscape.

1436

1437

Figure 9. (a) High glacis ferricrete relicts over southwestern Burkina Faso. (b) Corresponding geomorphic map reconstitution of the High glacis pediplain (modified after Grimaud et al., 2015).

1441 Figure 10. Idealized cross-sections of the successive landscape stages in West Africa. Black arrows locate the main river drains and white arrows the drainage divides. Such a landscape

1443 evolution model would typify the Soudanian or Sahelian zones (Fig. 2), where the original

1444 shapes of High and Middle glacis inverted landforms are preferentially preserved as plateaus 1445 (see Fig. 19).

1447 Figure 11. Detailed cross-section of a Middle glacis near Bania, ca. $100 \mathrm{~km}$ south of the Ivory

1448 Coast - Burkina Faso border (modified from Eschenbrenner and Grandin, 1970). Upslope

1449 part of the Middle glacis is an erosional, ferricrete-free surface exposing exhumed (old)

1450 saprolite that was turned into mottled clays at the surface. Downslope part of the glacis is

1451 erosional in the sense that it stripped-off the saprolite, but is depositional in the sense that it

1452 carries a detrital colluvial layer that passes downslope to river alluviums. The ferricrete

1453 developed by duricrusting of most of the transported material. A thin weathering layer

1454 developed into the bedrock under the downslope portion of the glacis. 
1456 Figure 12. Field illustrations of glacis conglomeratic overburdens. (a) Block-supported

1457 debris flow (High glacis near Timbou, Guinea). The cobble is a bauxite. (b) Heterogeneous

1458 debris-flow facies underlain by dolerite core stones (High glacis near Kokoro, Burkina Faso).

1459 Cobbles are made of bauxite. The fine-grained saprolite and mottled clay horizons are

1460 missing from this weathering profile, suggesting its truncation by the debris flow. (c) Debris-

1461 flow with bauxite (light colored) and Intermediate ferricrete clasts in a matrix made of iron oxy-hydroxide nodules and pebbles (High glacis, near Basnéré, Burkina Faso). (d)

1463 Conglomerate comprising exclusively Intermediate ferricrete clasts (Middle glacis, near Kaya,

1464 Burkina Faso). (e) Matrix-supported debris flow with Intermediate ferricrete cobbles

1465 (carapace of the Low glacis, near Matam, Senegal). (f) Basal alluvial channel carved in a

1466 sandstone saprolite (High glacis, south of Bobo Dioulasso, Burkina Faso). Channel material

1467 consists of quartz pebbles and iron nodules in a kaolinite-rich silty clay matrix. Cementation

1468 increases upward in the channel. Only cases (b) to (d) are ferricretes.

1470 Figure 13. Photograph (left) and interpretation (right) of a composite glacis ferricrete

1471 composed of a conglomeratic layer overlying a vermiform facies developed from the

1472 underlying mottle clays (High glacis, near Tikaré, Burkina Faso). The fine-grained material is

1473 likely preserved on its parental bedrock from which it derived by weathering. However, a

1474 transported origin cannot be precluded (see text for further explanation).

1475

1476 Figure 14. Glacis ferricretes derived from fine-grained material. (a) and (b) are exposed

1477 weathered surfaces and (c) and (d) are fresh cuts. (a) Fine-grained nodular ferricrete (Middle

1478 glacis, near Kedougou, Eastern Senegal). (b) Nodular ferricrete (High glacis, Niokolo Koba

1479 national park, Eastern Senegal). (c) Vermiform ferricrete (High glacis, near Kongoussi, 
1480 Central Burkina Faso). (d) Proto-nodular ferricrete (High glacis, near Tambakounda, Eastern

1481 Senegal). The iron oxy-hydroxides nodules are in dark grey / black. Nodular and vermiform

1482 ferricretes, and especially those exposed on weathered surfaces, should not be mistaken for

1483 conglomeratic ferricretes. Nodules generally have amoeboid / knucklebone shapes that

1484 distinguish them from gravels or cobbles.

1485

Figure 15. Type-logs of West African glacis. Bottom cross-sections illustrate potential

1487 geomorphic contexts of the logs. In (a), the ferricrete is confined to the cover conglomerate and underlain by a weathering profile derived from bedrock.

ferricrete extending beyond the base of the conglomerate (the conglomerate may also occupy part, or the entire thickness of, the carapace). (c) The ferricrete is restrained to the

1491 cover conglomerate that rests upon a truncated weathering profile. (d) Weathering profile

1492 developed from exhumed bedrock. (e) The glacis weathering profile affects both a fine-

1493 grained transported cover and the underlying bedrock. (f) Erosional surface exposing a

1494 truncated weathering profile (mottled clays formed at the surface). (g) Fine-grained cover

1495 overlying a truncated weathering profile. (h) Detrital sediments overlying a conglomeratic

1496 ferricrete. Question marks indicate contacts that may not be readily detected between

1497 comparable saprolites of contrasted origins (in-situ and transported). Emoticons refer to the

1498 suitability of the surface sampling medium for bedrock exploration geochemistry. The

1499 problem in (d) is that the ferricrete may not be distinguished from that in (e) (see text for

1500 further explanation). On the bottom cross-section, the residuum (mostly ferricrete and

1501 carapace) is shown by a single reddish color. Cover material and weathering horizons

1502 distribution patterns may be more uneven than shown on the cross-sections and further

1503 complexity may arise from later dissection / denudation.

1504 
1505 Figure 16. Denudation / weathering scenario for the establishment of a typical West African

1506 lateritic glacis system. (a) Cross-section of a common landform-regolith association. The old

1507 surface is preserved as a mesa capped by a duricrust topping in-situ formed weathering

1508 profile I (i.e., for instance, the Bauxitic or Intermediate landsfurface). The younger surface is

1509 a glacis whose development led to relief dissection of the upper/older surface. (b) Sequential

1510 development of the regolith profile for a given column located in (a). Stage 1 results from

1511 older weathering (and therefore dominant "chemical" denudation) leading to the

1512 establishment of landscape I and its underlying weathering profile (I). Stage 2 shows the

1513 configuration after shaping of the glacis by pedimentation, which has stripped off

1514 weathering profile I and eroded part of the underlying bedrock. Stage 3 shows the

1515 configuration after the weathering (II) and ultimate duricrusting of the glacis surface

1516 (ferricrete is restricted here to the transported overburden; e.g., case of Figs. 15a-15c) as a

1517 consequence of climate change. Columns in (a) and (b) are not to scale. Paleolandscape I

1518 could as well be a preexisting glacis. In this case, weathering profile I could already be

1519 composite (with an in-situ and a transported part).

1520

1521 Figure 17. Simplified geology (a) and regolith-landform map (b) of West Africa. Landform-

1522 regolith provinces are distinguished on the basis of the generation of landform-regolith

1523 association best preserved in the present-day landscape. (a) is adapted from Ye et al. (2017);

1524 (b) is from the present work. See Figure 2 for comparison with topography and climatic

1525 zonation. The sedimentary cover is overwhelmingly silico-clastic and mainly consists of

1526 sandstones and siltstones. The main rivers are shown both in (a) and in (b).

1527

1528 Figure 18. Paleo-zonation of the development and preservation patterns of the West African 1529 glacis systems (modified after Grandin, 1976). 
1531 Figure 19. Comparative scenarios of glacis ferricrete plateau degradation leading to a

1532 residual hill. (a) Under arid or semi-arid climate. (b) Under humid climate typical of rainforest

1533 environments (modified after Grandin, 1976).

1534

1535 Figure 20. Cross-section illustrating transport of mineralized material on successive glacis to

1536 form "transported" geochemical anomalies. The black star represents a surface geochemical

1537 anomaly expressed through a weathering profile and the white stars represent anomalies

1538 mechanically transported on glacis. Large grey arrows show material transport paths on

1539 glacis. Mineralization B first produced a dispersion halo and a surface anomaly through the

1540 old weathering profile. This mineralized weathering profile was then stripped off by

1541 pedimentation to form glacis 1, eventually leading to a transported anomaly on the new

1542 glacis surface. Formation of glacis 2 later led to reworking of the same mineralization that

1543 was still preserved under glacis 1. But this time, because of the creation of a new drainage

1544 divide, mineralized elements were transported in an opposite direction down the glacis 2

1545 slope. Bedrock mineralization B is currently concealed under glacis 2.

1546

1547 Figure 21. Gold and copper occurrences and High glacis ferricrete remnants overlying

1548 mineralized bedrock map units, Southwestern Burkina Faso (same map area as Fig. 9).

1549 Sources are Baratoux et al. (2011) and Metelka et al. (2012) for bedrock geology and Castaing 1550 et al. (2003) and the 1/200,000 scale geological maps for mineral occurrences (artisanal and 1551 industrial mining sites, prospects and soil geochemical anomalies). Specific mineralized 1552 bedrock map units such as detrital sediments and ultramafic rocks are too small to be 1553 represented at this scale ( 4 and $0.4 \mathrm{~km}^{2}$ for the entire map area, respectively).

1554 


\section{LOG WEATHERING HORIZONS}

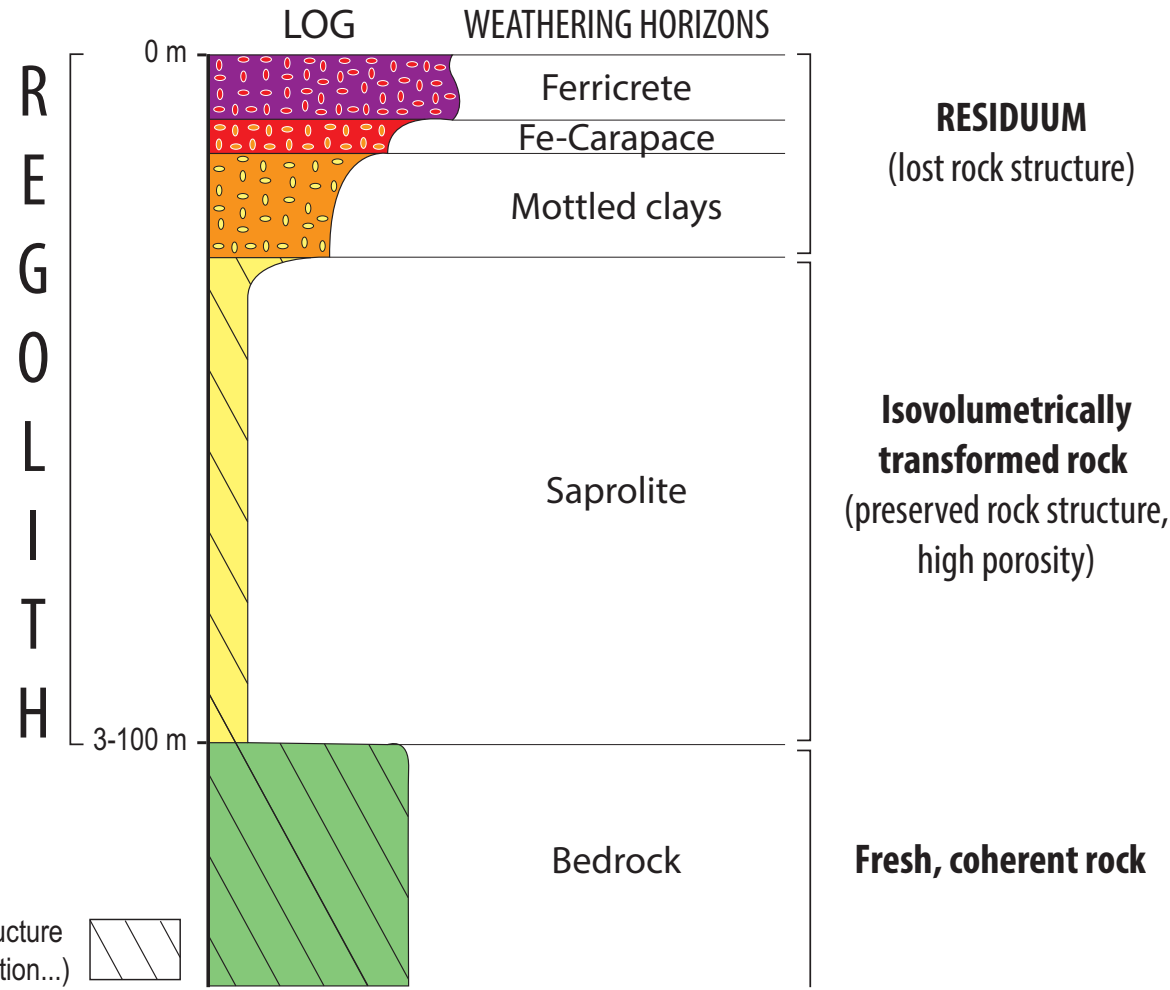

Chardon et al., Figure 1 

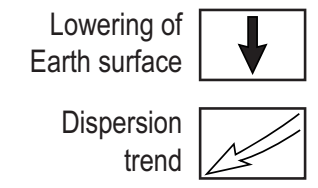

Dispersion halo (e.g., $0.1 \mathrm{~g} / \mathrm{t} \mathrm{Au}$ )

Mineralized structure

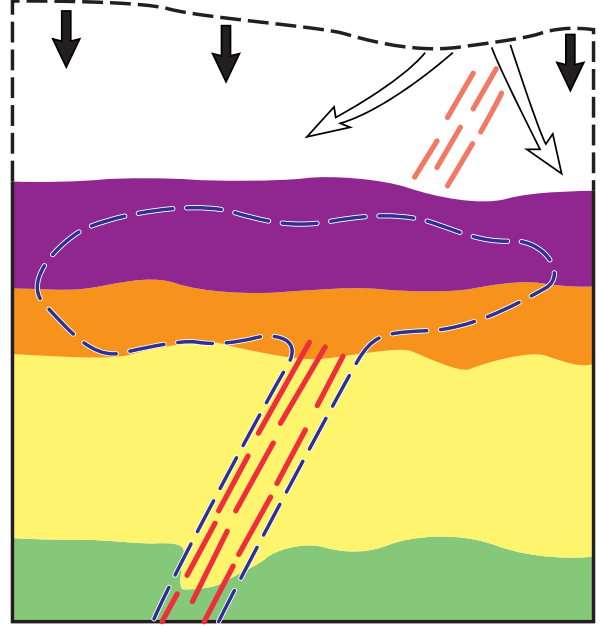

Lateritization-driven denudation

Ferricrete

Mottled clays

Saprolite

Bedrock 
REGOLITH = GLACIS SEDIMENTARY COVER \& UNDERLYING WEATHERED SUBSTRATE

REGOLITH = WEATHERED BEDROCK Abandonment age $(\mathrm{Ma})$ 45

\section{Bauxitic landscape (African Surface)}

(a)

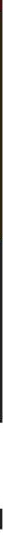

TYPE OF CRUST

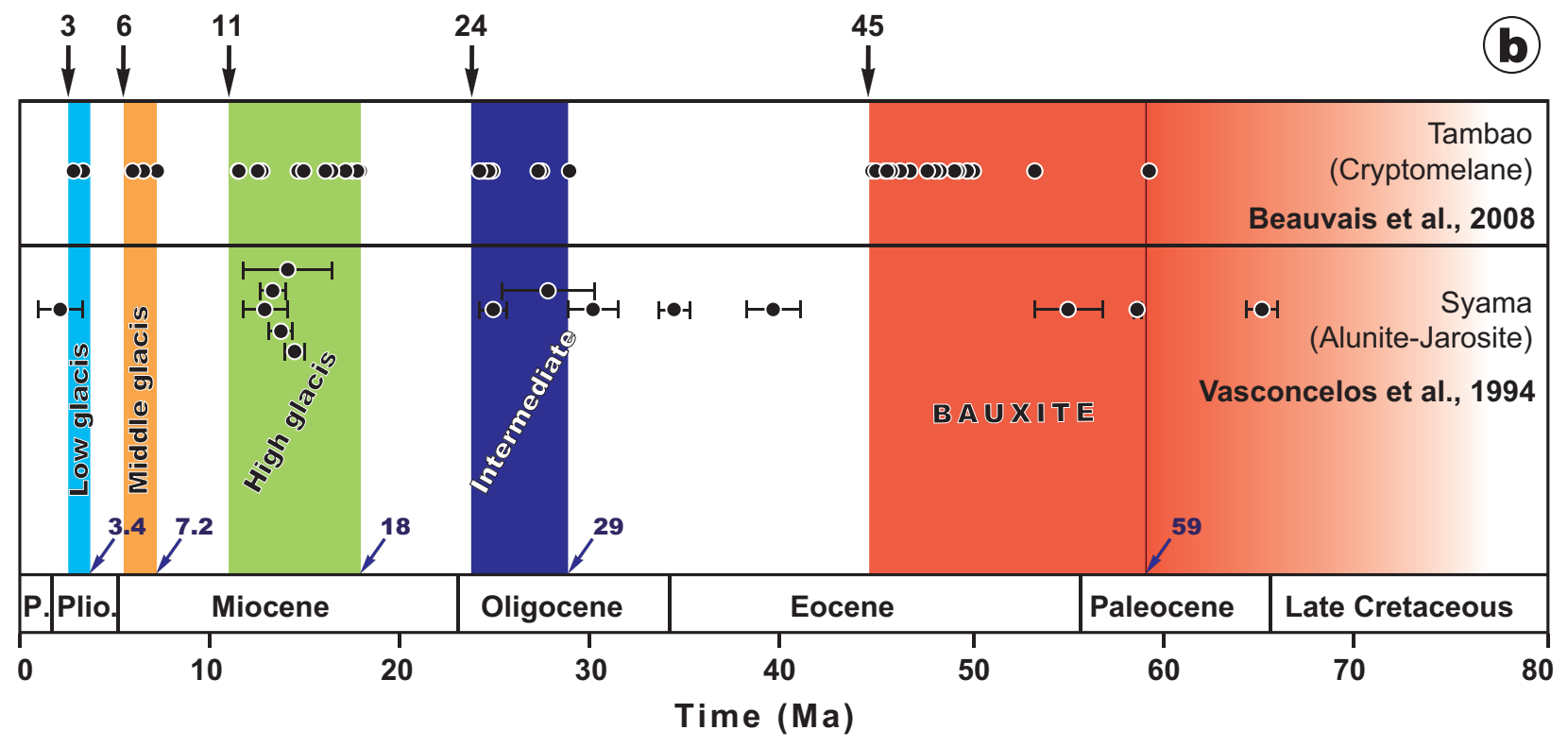

\section{Chardon et al., Figure 4}




\section{(a)}
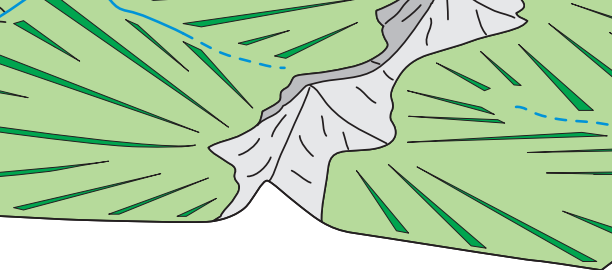

(b)

C

Chardon et al., Figure 7 


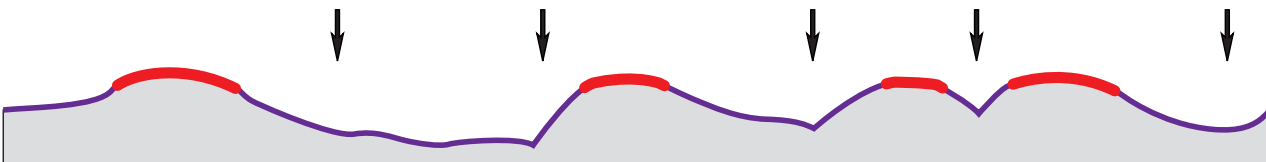

$\varepsilon$
$\varrho$
$\varrho$

Intermediate (doubthouse) 45 - $24 \mathrm{Ma}$

Physical \& chemical

$5-20 \mathrm{~km}$

$\varepsilon$
$\stackrel{8}{\circ}$

$5-20 \mathrm{~km}$

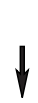

5 - $20 \mathrm{~km}$
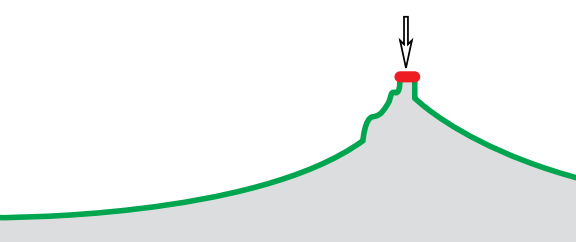


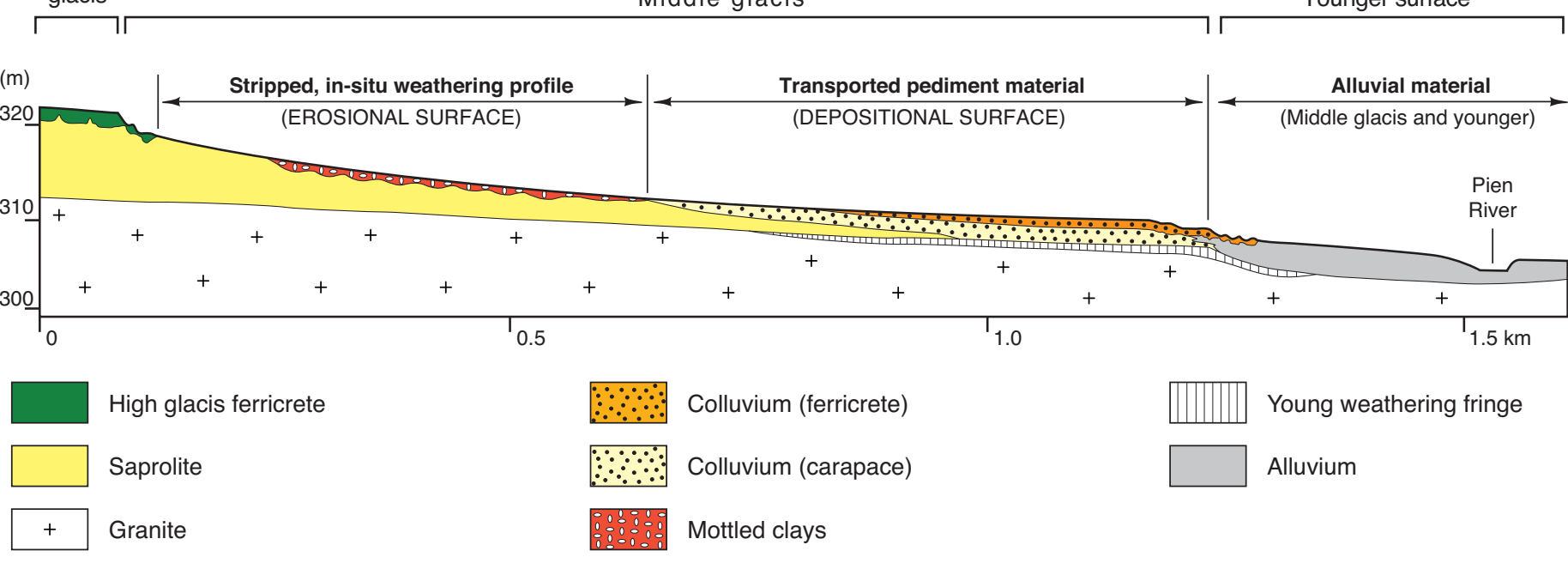

\section{Chardon et al., Figure 11}



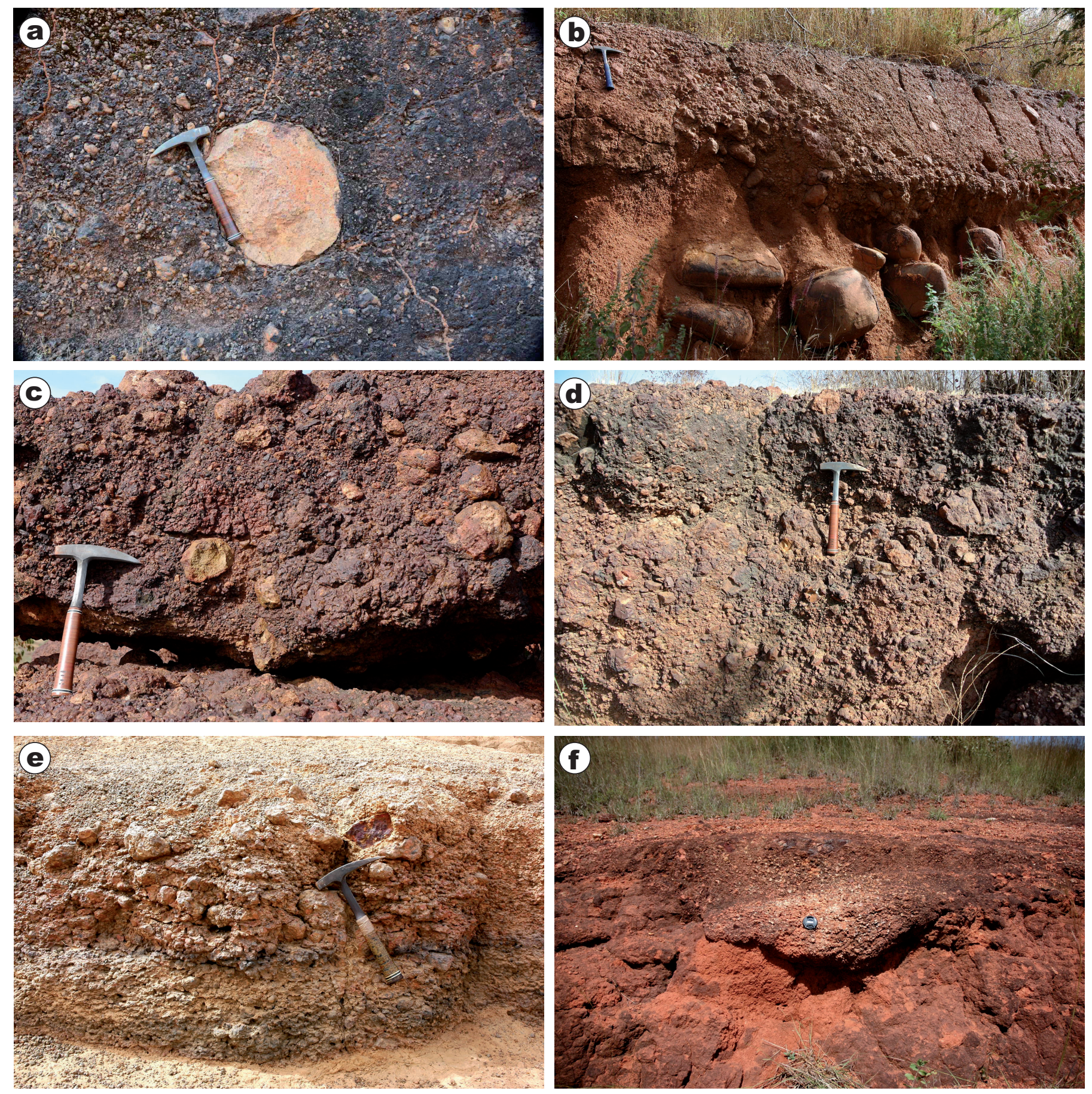

Chardon et al., Figure 12 

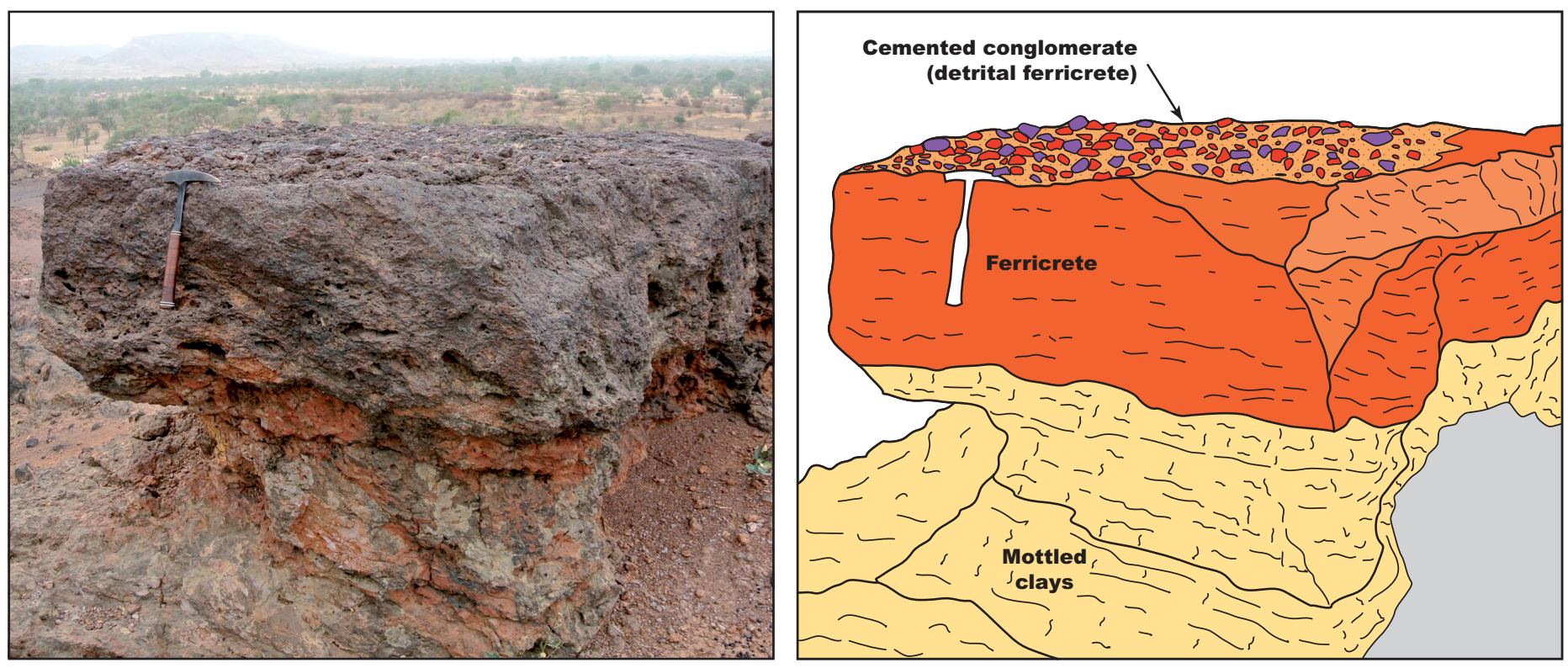

\section{Chardon et al., Figure 13}



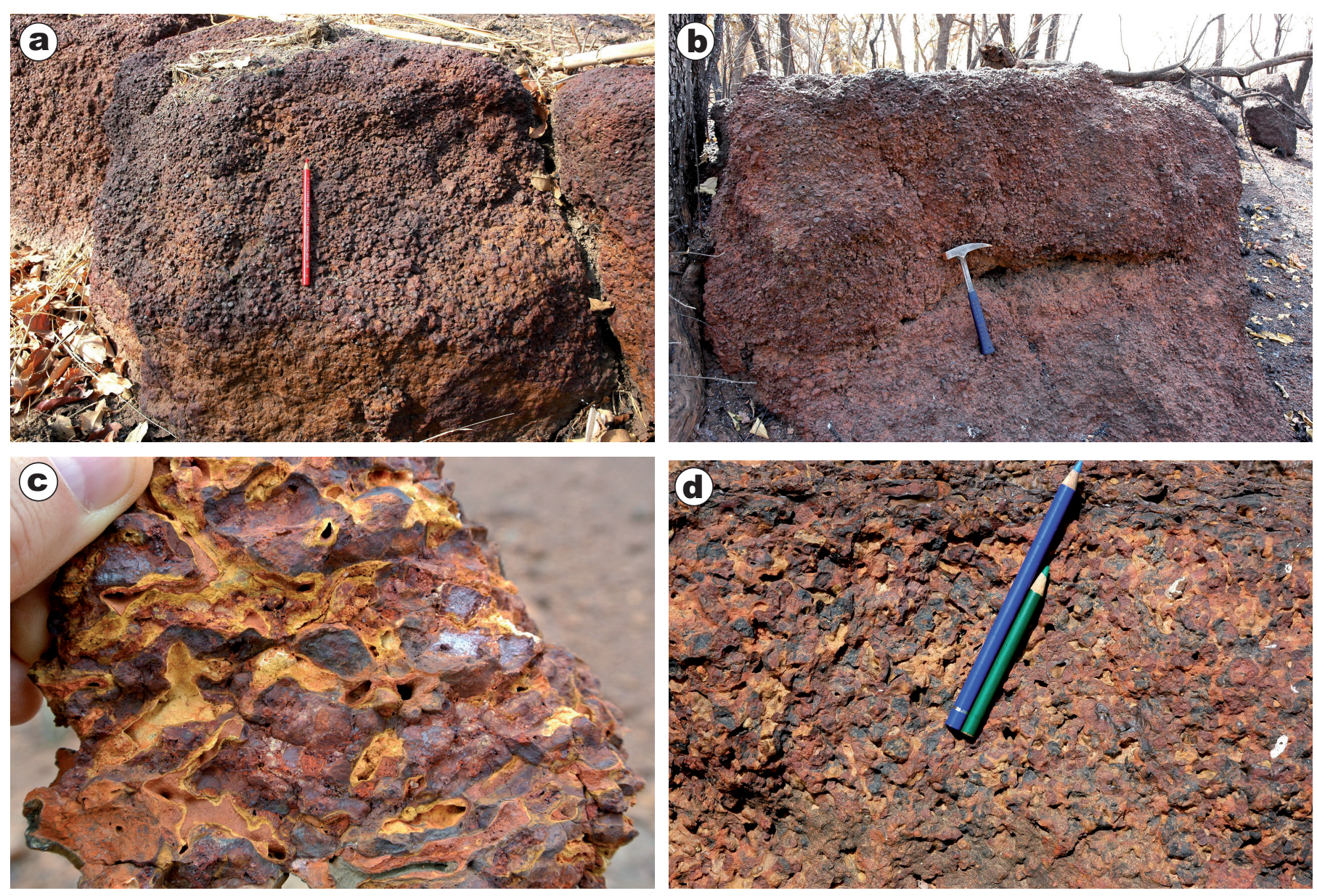

Chardon et al., Figure 14 


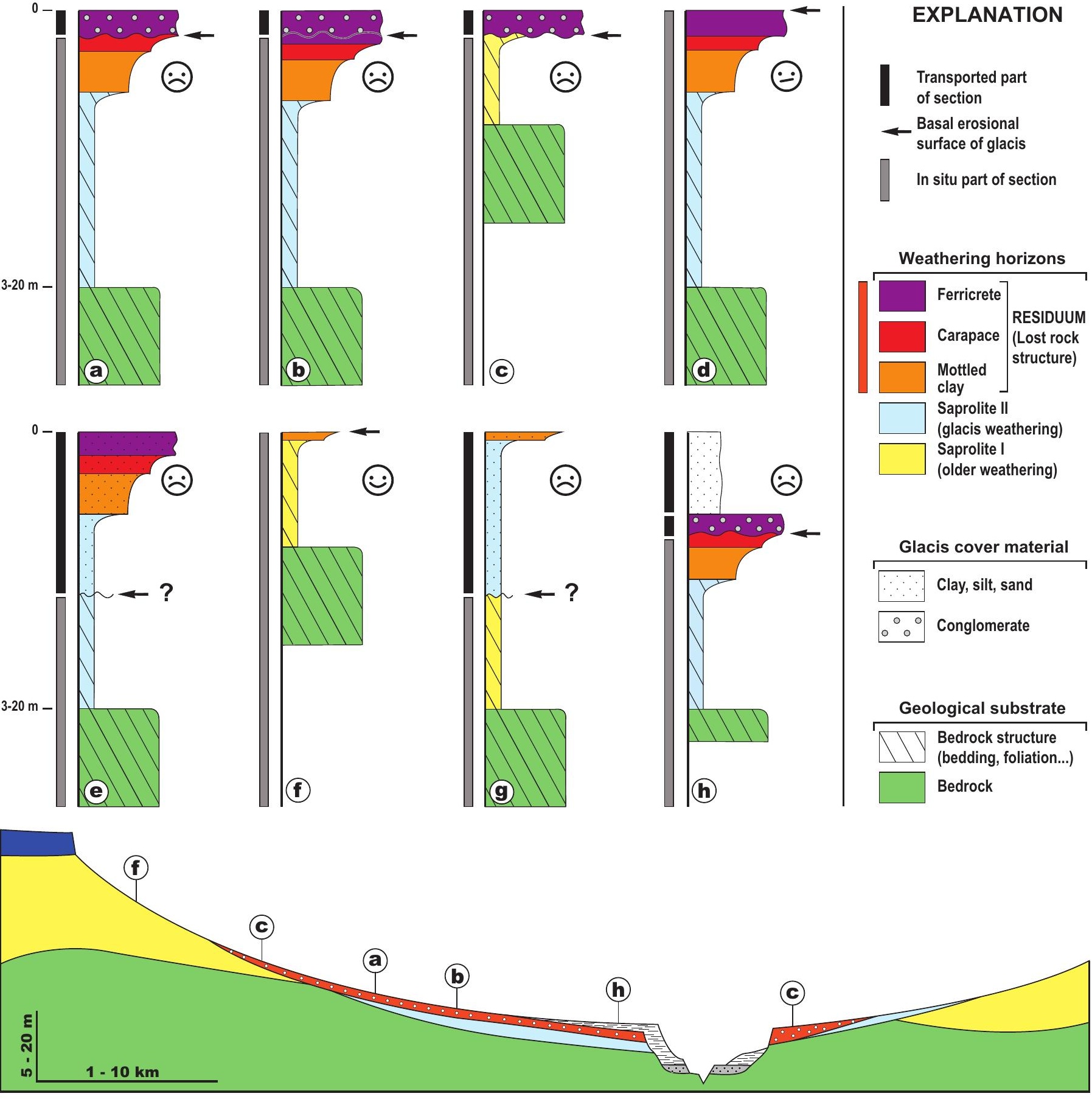

(f)

(f) 


\section{Topographic paleosurface I}

$\left[\begin{array}{l}1 \\ \overrightarrow{0} \\ 1 \\ \overrightarrow{8} \\ 3\end{array}\right.$

Surface (II)

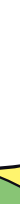

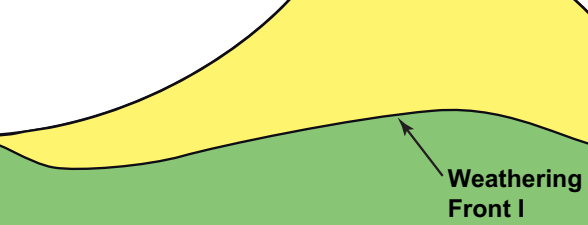

$\sim 1-10 \mathrm{~km}$

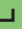

Weathering

Front II

(b)

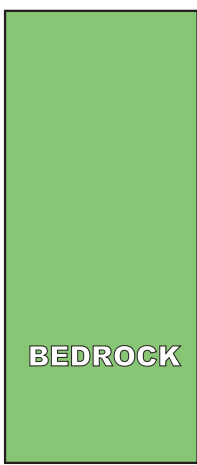

(1) End of old weathering

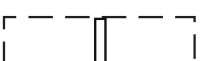

'

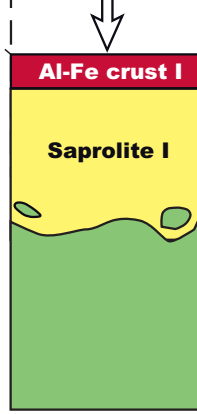

(2) After glacis abandonment 1 - - - -

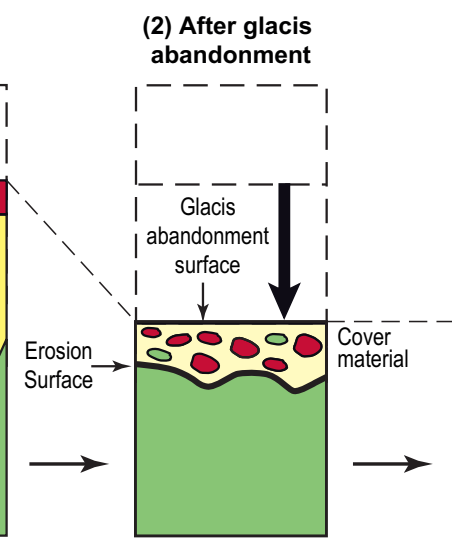

(3) After glacis

- - - - -

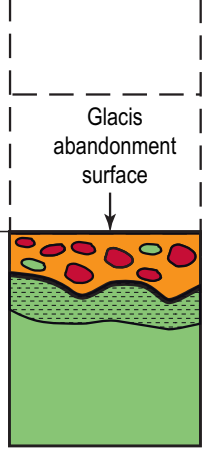

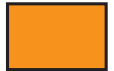

Glacis

ferricrete

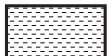

Weathering profile II

Transported

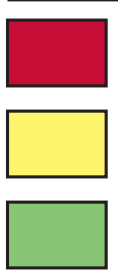

Al-Fe crust I

Weathering

Profile I
Weathering

Profile II saprolite

Saprolite I

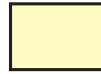

Bedrock 


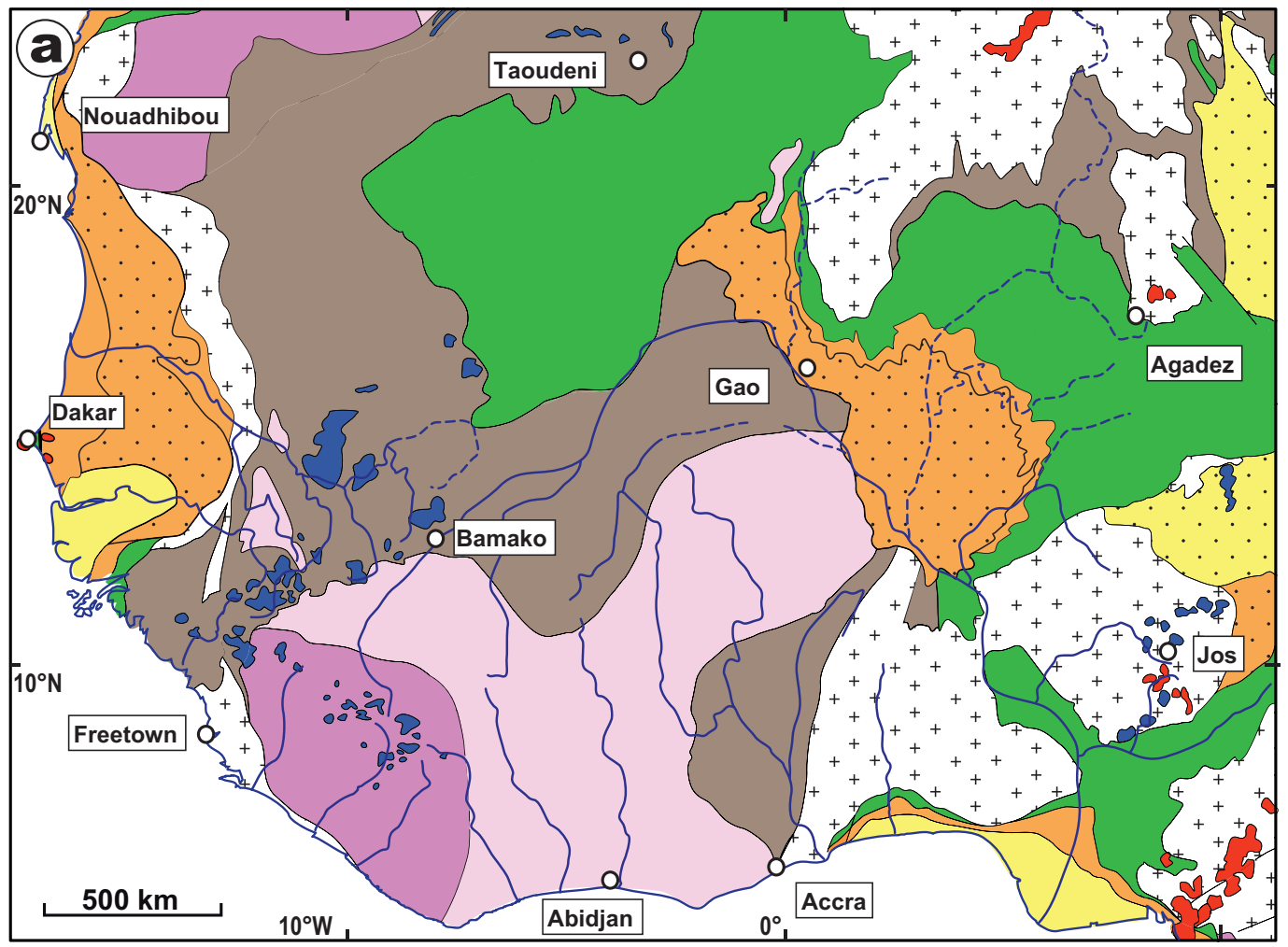

SEDIMENTARY COVER

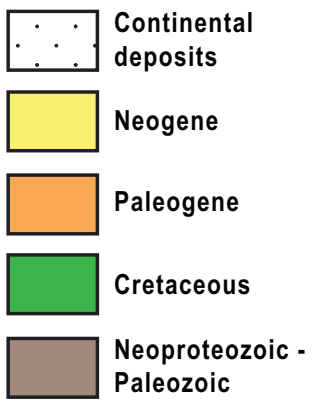

\section{CRYSTALLINE ROCKS} $\&$ VOLCANICS
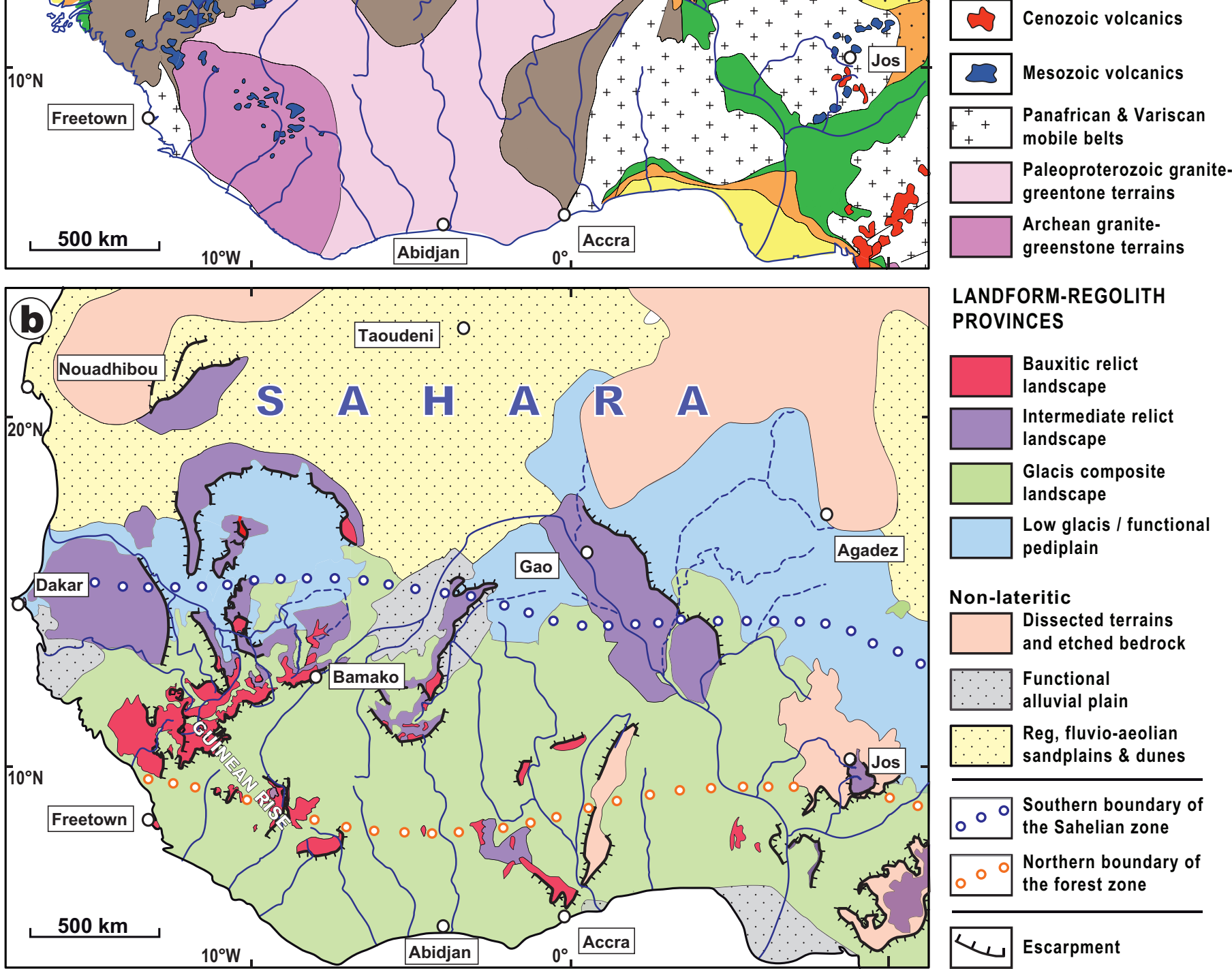

\section{LANDFORM-REGOLITH PROVINCES}

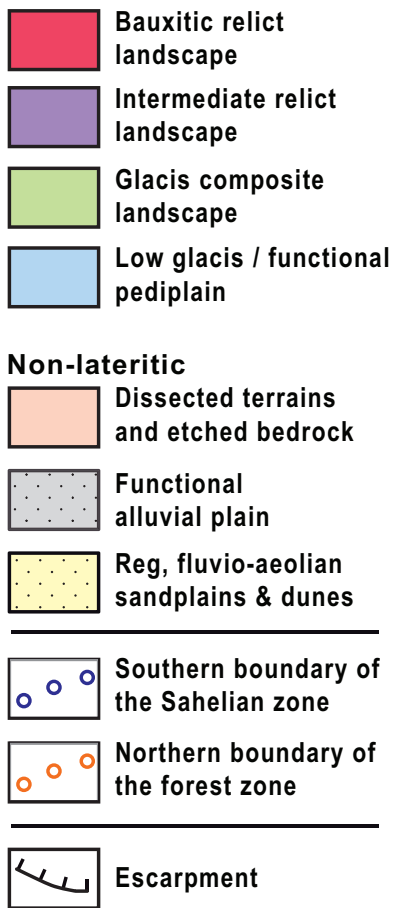

Chardon et al., Figure 17 


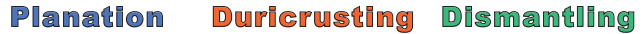

HIGH GLACIS

(24 - $11 \mathrm{Ma})$

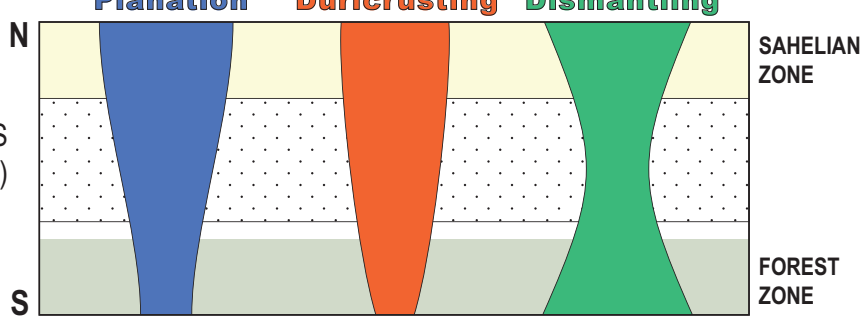

MIDDLE GLACIS

(11 - $6 \mathrm{Ma})$

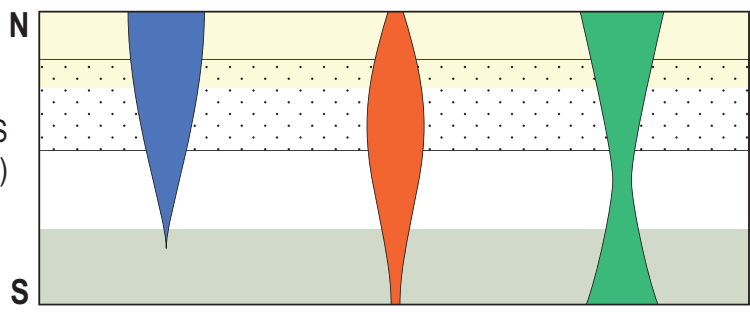

SAHELIAN

ZONE

LOW GLACIS

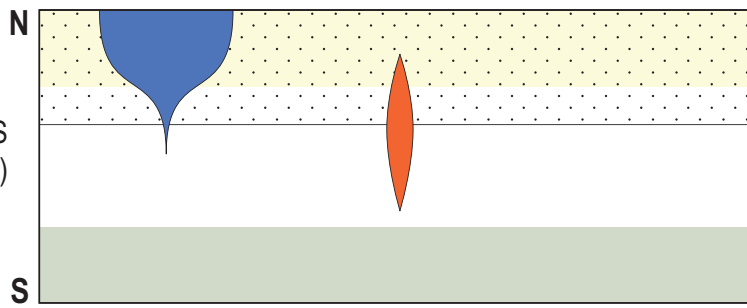

\section{FOREST \\ ZONE \\ SAHELIAN \\ ZONE}

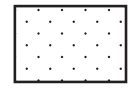

Zone of current

optimal preservation 

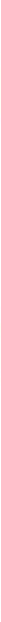

\section{Chardon et al., Figure 19}


over mineralized rock units

MINERAL OCCURENCES

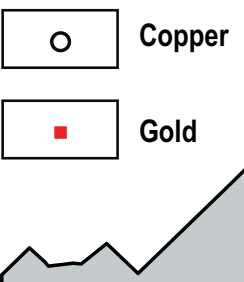

Copper

\section{MINERALIZED GRANITE-GREENSTONE GEOLOGICAL MAP UNITS}

Tô

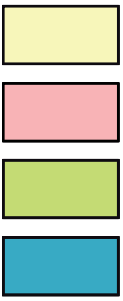

TTG

Granitic plutons

Volcanosediments

Basalts and andesites

\section{OTHER BEDROCK LITHOLOGIES}

Tabular sandstone of

the Taoudeni basin

Undifferentiated granitegreentone lithologies 